NBER WORKING PAPER SERIES

\title{
EFFECT OF AN ABRUPT CHANGE IN SEXUAL AND REPRODUCTIVE HEALTH POLICY ON ADOLESCENT BIRTH RATES IN ECUADOR, 2008-2017
}

\author{
Omar Galárraga \\ Jeffrey E. Harris \\ Working Paper 26044 \\ http://www.nber.org/papers/w26044 \\ NATIONAL BUREAU OF ECONOMIC RESEARCH \\ 1050 Massachusetts Avenue \\ Cambridge, MA 02138 \\ July 2019
}

The authors would like to thank three anonymous referees, Dhaval Dave, Rachel Robinson, Kathleen Broussard, Vladimíra Kantorová, and participants in the 4th Annual Population Health Science Research Workshop at University of Pennsylvania (December 2019) and at the Population Association of America (PAA) virtual meetings (April 2020) for useful discussions and comments. James Kunhardt (at Brown University, Department of Economics) provided excellent research assistance. We are grateful also to the Population Studies and Training Center (PSTC) at Brown University, which receives funding from the National Institutes of Health (NIH: P2C HD041020), for general support. The authors have no conflicts of interest to declare. The views expressed herein are those of the authors and do not necessarily reflect the views of the National Bureau of Economic Research.

NBER working papers are circulated for discussion and comment purposes. They have not been peer-reviewed or been subject to the review by the NBER Board of Directors that accompanies official NBER publications.

(C) 2019 by Omar Galárraga and Jeffrey E. Harris. All rights reserved. Short sections of text, not to exceed two paragraphs, may be quoted without explicit permission provided that full credit, including $(\odot)$ notice, is given to the source. 
Effect of an Abrupt Change in Sexual and Reproductive Health Policy on Adolescent Birth

Rates in Ecuador, 2008-2017

Omar Galárraga and Jeffrey E. Harris

NBER Working Paper No. 26044

July 2019

JEL No. I12,I18,J13,J18

\begin{abstract}
$\underline{\text { ABSTRACT }}$
Several countries have implemented "family-centered" abstinence-only policies for teenagers, as opposed to encouraging utilization and expansion of reproductive health services and education. Little is known, however, about the effects of these more restrictive policies on adolescent birth rates at the national level or their differential effects by race and ethnicity. The extant literature is even scarcer in low-and middle-income countries. We analyze an unexpected policy change in Ecuador that abruptly reversed course and restricted reproductive health services for teenage women in 2014. We use a canton- and time-fixed effects difference-in-differences analysis of Ecuador's 221 cantons with time-varying controls to analyze the impact of the abrupt policy change on the difference of teen (15-19 years) minus young adult (20-24 years) birth rates. In a difference-in-difference-in-differences analysis, the policy change increases birth rates by 8.5 births per 1000 women in cantons with higher indigenous concentration. Results are robust to changes in the comparison population (young adults vs. women in their late 20s or in their early 30s), pre-intervention control periods, population weighting, serial correlation, logarithmic model specification, adjustments for intervention year, definition of indigenous concentration, and potential delays in policy implementation.
\end{abstract}

Omar Galárraga

Brown University

International Health Institute

School of Public Health

121 S. Main St.

Providence, RI 02912

Omar_Galarraga@brown.edu

Jeffrey E. Harris

Department of Economics, E52-422

MIT

77 Massachusetts Avenue

Cambridge, MA 02139

and NBER

jeffrey@mit.edu 


\section{Introduction}

Latin America has the second highest teen birth rate (defined as births per 1,000 women aged 15-19) in the world, only behind sub-Saharan Africa, which has lower economic development (The Economist, 2019). The United Nations Population Fund identified eight Latin American and Caribbean countries where 20 to 30\% of women ages 20-24 reported a birth before age 18: Colombia, Bolivia, Ecuador, El Salvador, Guatemala, Dominican Republic, Honduras, and Nicaragua. (No data reported for Venezuela.) (UNFPA, 2013).

Teen pregnancy imposes high economic costs on individuals and societies largely through lower educational achievement (fewer years of formal schooling; lower probability of graduating from high school), and higher reliance on family support and public assistance programs (Azevedo et al., 2012; Berthelon and Kruger, 2011; Buvinic, 1998; Marteleto and Villanueva, 2018). Several studies using a variety of methods point to the detrimental effects of teen pregnancy, including lower wages and lower access to tertiary education (Diaz and Fiel, 2016); as well as adverse effects on other family members including siblings (Heissel, 2017).

Few studies assess the causal effects of health policies on teen sexual and reproductive health (SRH) outcomes, with most focusing on the United States where teen pregnancy is highest compared to other developed nations (Kearney and Levine, 2015, 2012). Abstinence-only programs continue to be proposed in the U.S. and elsewhere although evidence does not support their effectiveness (Trenholm et al., 2008; Underhill et al., 2007). A difference-in-differences (DD) study of state-level data from the U.S. covering 2000-2011 found that state-mandated abstinence-based sexual education policies had no effect on teen birth rates or abortion rates, but may have increased the incidence of sexually transmitted infections (STIs) (Carr and Packham, 2017). Another DD study compared the changes in teen birth rates in Texas counties that lost family planning funding to changes in counties outside of Texas with publicly funded clinics. Reductions in funding for family planning services in Texas increased teen birth rates by 3.4\% during 2011-2014 (Packham, 2017). 
Studies of low- and middle-income countries (LMICs) are even scarcer. One DD study based on South Africa relied upon geographic variation in the rollout of the National Adolescent Friendly Clinic Initiative (NAFCI) during 2000-2010. The investigators found that living near an NAFCI clinic delayed childbearing by 0.5-0.7 years (Branson and Byker, 2018). Another DD paper studied the impact of a major expansion of the Indonesian midwife program, which sent over 50,000 midwives to over 52,000 communities, principally during 1993-1997. The SRH services provided by the midwives included oral and injectable contraceptives and implants. Women aged 13-20 years who lived in a participating community delayed their first birth by an average of 0.96 years (Strupat, 2017).

The present paper fills an important gap in the literature as it addresses the question: How much can restrictive access to SRH services affect teen birth rates? To answer this question, we analyze a policy in Ecuador that severely limited access to SRH services among adolescents. We find that the more restrictive access to SRH services increased the adolescent birth rate in Ecuador, particularly in the areas with a higher concentration of indigenous women. This paper is, to our knowledge, the first to estimate a causal effect of an abrupt policy change on SRH outcomes in Latin America. Specifically, this study focuses on effects on teen birth rates and, consequently, addresses one of the most important public health policy issues in the region. The identifying assumption is that absent the sudden policy change, teens (15-19 years) and young adults (20-24 years) would have experienced similar changes in birth rates.

Various pieces of evidence provide support to the identifying assumption. First, we provide graphical and statistical evidence that the trends for the two groups were similar prior to the sudden reversal in SRH policy. We exploit a constructed-panel structure for 221 cantons for 10 years, to enable a canton- and time-fixed effects, triple difference (DDD) regression specification. The first difference is between teen and young adult birth rates, the second difference is for cantons above or below the mean of indigenous women concentration, and the third difference is for before and after (3-4 years of) program exposure. Furthermore, we show that including time-varying control variables or changing various parameters through robustness tests does not qualitatively affect the main results. 
The DDD analysis shows that the policy change increased the birth rate difference (teens minus young adults) by 8.5 births per 1000 women in cantons with a higher indigenous concentration (as compared to cantons with lower indigenous concentration). This represents a $27 \%$ change from a baseline of a 31 -point difference between young minus young adult birth rates. The main results are robust to changes in the comparison population (young adults versus women in their late 20s, or versus women in their early 30s), preintervention control periods, population weighting, logarithmic model specification, adjustments for intervention year, definition of high indigenous concentration, and potential delays in policy implementation.

The rest of the paper proceeds as follows. In the next section, we present essential background information. Then we summarize our analytical methods and empirical strategy. We proceed to present the main results, followed by a series of robustness tests. A discussion of the results occupies the last section, along with limitations and potential paths for future research.

\section{Background}

On February 28, 2015, President Rafael Correa of Ecuador publicly clarified his rationale for the new Plan Familia, which had gone into effect by presidential decree three months earlier on November 26, 2014 (Correa, 2015; Official Register, 2014). Correa attacked the now defunct Inter-Sectoral Strategy for Family Planning and Prevention of Adolescent Pregnancy (ENIPLA for its initials in Spanish), which had formally been in effect nationwide since 2011. Although he acknowledged that births among adolescents aged 12-19 had dropped significantly under the ENIPLA program, Correa claimed that the ENIPLA strategy was completely misguided in its promotion of "hedonism.” ENIPLA talked only about "pleasure, a terrible message,” Correa asserted, “... and if you have problems, go to the health center. But the foundation of our society is not the health center, it's the family." Correa continued, "We have to enable the parents. The remedy was worse than the disease. It broke the bond with the family." (Correa, 2015) [p.4]. In contrast to ENIPLA, which offered sexually transmitted disease testing and treatment as well as short- and long-term contraceptive services through teen-friendly clinics at local health centers, the new Plan Familia would rely on education through the family, with a focus on 
abstinence and delayed initiation of sexual activity (Presidencia de la República del Ecuador, 2015). The government's educational materials encouraging condom use under ENIPLA, such as the pamphlet in Figure 1, would be prohibited under Plan Familia (Estrella, 2015). While the ministries of public health, education, and economic and social integration had jointly taken charge of ENIPLA, the new Plan Familia would be under the direct control of the president.

\section{[FIGURE 1 ABOUT HERE.]}

To motivate the research strategy, we first suggest that the impact of the policy change is not clear from a simple comparison of self-reported outcomes. For example, Appendix Figure A1 plots historical trends in sexual activity and contraceptive use among teens in the last two nationally representative health surveys. Teenage women were less likely to report being sexual active in 2018 than in 2012 (31 vs. 39\%); and if they were sexually active already, they were slightly more likely to use birth control in the 30 days preceding the survey (52 vs. 47\%). Similarly, Appendix Table A1 uses ENSANUT 2012 and 2018 to analyze the trajectories of contraception use among teenage women and compare them to those of young adult women. The top (Panel A) presents contraceptive methods ever used: over three quarters of teens (78\% in 2012 and $82 \%$ in 2018, columns 1 and 4) report having used some method at some point; meanwhile, a large majority of young adult women (89\% in 2012 and 92\% in 2018, columns 2 and 5) report having ever used some method. Furthermore, compared to young adults, teens were less likely to use any contraception method in a given year (columns 3 and 6); and they were also less likely to use any method over time and in comparison to young adults (column 7). We found similar patterns when we analyzed methods currently used now (Panel B). Yet, these were selfreported outcomes, and at only two points in time that do not fully coincide with the beginning and the end of the intervention.

Our premise here is that the full registry of births over a decade are a more accurate indicator of the impact of changes in SRH policies than self-reported contraceptive use in two repeated cross sections. We focus specifically on the impact of the abrupt change in SRH policy on teen birth rates in Ecuador. To that end, we 
treat the unanticipated shock of the replacement of ENIPLA with Plan Familia as a natural experiment (Craig et al., 2017). To address the alternative hypothesis that the observed patterns of birth rates were actually due to trends independent of the government's sudden reversal in SRH policies toward adolescents, we use a DD approach, comparing birth rates of teens aged 15-19 years with those of young adults aged 20-24 years. In contrast to adolescents, whose access to contraceptives was curtailed after 2014, young adults continued to have access to short- and long-term contraceptives at health centers through other government programs (Bucheli et al., 2014). ENIPLA was formally established as a government program in 2011 focused specifically on adolescent women ages (10-19) (Ministerio Coordinador de Desarrollo Social, 2011). Additionally, there is evidence that non-governmental organizations had set up some teen-friendly programs at health centers during the pre-ENIPLA period from 2008-2010 (Burneo Salazar et al., 2015; MSP, 2018). These included differentiated services for adolescents, offered by well-sensitized and trained general providers (Goicolea et al., 2017). Accordingly, we study the interval from 2008-2017, covering the pre-ENIPLA period from 2008-2010, the ENIPLA period from 2011-2014, and the Plan Familia period from 2015-2017.

Here, we focus on birth rates, rather than pregnancy rates, for two reasons. First, there is no uniform record of all pregnancies as there is for live births; and the live birth rate is the actual outcome of interest. Second, abortion is not legal (even in cases of rape), and generally not observable in Ecuador, to the extent that it occurs (Reuters, 2019). We calculate birth rates at the level of the county ("cantón"), which we treat as our fundamental unit of observation. We reason that the SRH services provided by ENIPLA and its predecessors were delivered in local health clinics in each canton, and that the density and intensity of services thus varied across counties.

To assess whether the abrupt switch to Plan Familia had a disproportionate effect on the most vulnerable populations, we stratify birth rates in each canton not only by age group, but also by the presence of a substantial indigenous population. We then use a difference-in-difference-differences (DDD) approach, further distinguishing between counties (“cantones") with high and low proportions of indigenous women. Ecuador's ministry of public health (MSP for its initials in Spanish) has emphasized that, when it comes to the indigenous 
population: "adolescence does not exist as part of the cycle of life. To the contrary, childhood transitions to youth, and with that, one acquires a social role differentiated from boys and girls. This type of 'invisibility' of adolescence is associated with marriage at very early ages...” (MSP, 2012) [p. 131]

Generally, teen pregnancy has deleterious consequences for employment and educational outcomes among all ethnic groups. Most teens and young women who got pregnant and were studying or working report that they stopped working and did not return to work (39.4\%), or stopped studying and did not return to school (44.3\%) (Freire et al., 2015) [p. 285]. As a consequence, indigenous women have the lowest rates of knowledge, use, and access to sexual and reproductive services.

In terms of knowledge, most indigenous women (87.3\%) did not know of any contraception method [ibid. p.130]; and were the ethnic group with the least knowledge about sexually transmitted infections. For example, only about two thirds of them (68.2\%) had heard about HIV/AIDS; and of them, a third did not know how to avoid getting HIV (32.8\%) [ibid. pgs. 296, 301, 305]. Indigenous women also were the ethnic group with the least information about the three main ways to prevent HIV acquisition: condom use (38.6\%), mutually monogamous relationship (30.4\%) or abstinence (16.6\%) [ibid. p.308]. Conversely, over a third of indigenous women (36.3\%) endorsed that HIV could be transmitted by using eating utensils used by a person living with HIV, and about a fifth (18.4\%) thought they could get infected by shaking hands with someone living with HIV [ibid. p.309]. Indigenous women were the ethnic group with the lowest rates of knowing about the HIV test, where they could obtain it, or having taken it (53.7, 68.5 and 54.8\% respectively) [ibid. p.312].

In terms of actual practices, $20.7 \%$ of indigenous women did not use a condom in their last sexual encounter because they had never used it; a rate that is three times higher than other groups [ibid. p.335]. Similarly, indigenous women had some of lowest rates of using any contraception (65.8\%) [ibid. p.143]; while a fifth (19.8\%) had never used any [ibid. p.148].

With respect to access, three quarters $(76.8 \%)$ of indigenous people did not have any health insurance; and they were the ethnic group least likely to be hospitalized (2.9\%) if they had a health problem in the 30 days 
prior to the survey [ibid. p.352]. Rather than seeing a healthcare professional, self-medicating, or seeking care at home, indigenous people are the ethnic group most likely to do nothing about their health problems (19.1\%)

[ibid. p.359]. Indigenous women were the group with the highest proportion who did not undergo any prenatal care (17.4\%) [ibid. p.380]; the highest group to give birth at home (15\%). They also exhibited the highest rates of unplanned pregnancies (17.1\%) and highest fertility rates (3.4 children per woman) [ibid. p.119]. If they do access contraception, indigenous women are most likely to go to a public health center run by the Ministry of Health [ibid. p.137].

\section{Correa's sudden reversal}

Returning to Ecuador after receiving his Ph.D. in economics, Rafael Correa became minister of economy and finance under then-president Alfredo Palacio. In that capacity, he lobbied Congress for increased spending on health and education. Campaigning against what he characterized as Ecuador's neo-liberal elites, he was elected as president in 2006 and took office in January 2007. Overseeing the introduction of a new national constitution in 2008, Correa was re-elected in 2009 and again in 2013. During his tenure, Correa fashioned his own brand of socialist revolution, increasing government spending generally and in particular on health. He raised the minimum wage to combat poverty, and increased physicians' salaries.

In the face of a long career of leftist policies, why did Correa perform a 180-degree turn on sexual and reproductive health policy at the start of his third and final term in office? This question can be framed within the political agency model (Galárraga and Harris, 2019). Correa, having entered his third term and facing no further prospect of re-election, abruptly changed his posture away from the public interest and in favor of his private interests in conformance with his Catholic faith. Although the country has had official separation of church and state since at least the 1906 constitution, and re-affirmed that separation in 2007, Correa himself used his powers to oppose legal abortion, even in cases of rape (Nicolalde-Escobar, 2016). For Plan Familia, in particular, the official posture was that adolescents would now need to discuss any sexual reproductive issues first within their own families (i.e., with their parents). Thus, family-centered policies become the guiding 
norm, undermining the previous ENIPLA policies, which provided free and easier access to contraception for adolescents (Paz-y-Miño, 2014).

\section{Methods}

\subsection{Data}

Our numerator data for the birth rates come from detailed live birth registry records released by Ecuador's Institute of Statistics and Census (Instituto Nacional de Estadísticas y Censos, INEC) for the years 2008-2017 (about 350,000 births per year), available at http://www.ecuadorencifras.gob.ec/nacimientos-bases-de-datos/. The live birth registry provides the mother's province and cantón of residence, as well as her age, marital status, ethnic/racial self-identification, and education. Data on each birth also include: place of delivery, prenatal control, prior pregnancies and births, birth attendant information. We merged all of these data for 10 years (about 3.5 million births) including all births that occurred in a given calendar year $(t)$, regardless of when they were registered, i.e., including registrations in any subsequent year $(t+\tau)$ (Carrera and Yunga, 2016).

The denominator for the birth rates comes from the last Census (Censo de Población y Vivienda, CPV) conducted in Ecuador in 2010 (containing records for over 14 million people), available at http://www.ecuadorencifras.gob.ec/base-de-datos-censo-de-poblacion-y-vivienda/. The population data for before and after the census year are taken from the INEC's Official Population Projections for each province and canton (with 221 cantones with pre- and post-census year data), available at http://www.ecuadorencifras.gob.ec/proyecciones-poblacionales/.

Background information on sexual activity and contraception methods utilization come from the National Health and Nutrition Survey (Encuesta Nacional de Salud y Nutrición, ENSANUT), which collected health and nutrition information from 19,949 households in 2012, and from 43,311 households in 2018. Topics included anthropometric, blood and urine measurements, tobacco and alcohol use, physical activity, diet (through a 24hour food recall diary), as well as issues of health care use and access. ENSANUT also includes a detailed 
module on sexual and reproductive health for women of reproductive age (10-49 years), available at https://www.ecuadorencifras.gob.ec/salud-salud-reproductiva-y-nutricion/.

\subsection{Econometric analysis}

Main econometric specification. We define the birth rate Delta $1\left(\Delta 1_{j t}\right)$ as the difference between the teen (15-19) and young adult (20-24) birth rates in each canton $j$ in each year $t$. Thus, larger values of $\Delta 1_{j t}$ imply higher teen birth rates while lower (even negative) values imply higher young adult birth rates. We employ differences-in-differences (DD) and triple difference (DDD) approaches, estimating regressions of the form:

$$
\text { (1) } \Delta 1_{j t}=\alpha^{1} I N D_{j t}+\alpha^{2} I N D_{j t} \times \text { Post }_{t}+\boldsymbol{\alpha}_{t}^{3}+\boldsymbol{\alpha}_{j}^{4}+\boldsymbol{\alpha}^{5} Z_{j}+\varepsilon_{j t}
$$

where, Post $t_{t}$ is a binary indicator that the year $t$ is after 2014, when Plan Familia started. The variable $I N D_{j t}$ is a binary indicator that the percentage of women in canton $j$ who self-identified as indigenous in year $t$ exceeded the canton national average of $12 \%$. The coefficient $\alpha^{2}$ of the interaction term $I N D_{j t} \times$ Post $_{t}$ gives the triple difference (DDD) estimator. In addition, $\boldsymbol{\alpha}_{t}{ }^{3}$ are year fixed effects to control for shocks to teen birth rates that are common to all cantons in a year, and $\boldsymbol{\alpha}_{j}^{4}$ are canton fixed effects to control for any time-invariant systematic differences across counties. Finally, the vector $Z_{j}$ refers to time-varying canton-specific characteristics, including canton-level means for age, years of education, and proportion indigenous; as well canton-level rates for: married/in-union, institutional delivery, skilled birth attendance, at-least-one-prenatal-control, second-orhigher-order-child. We estimated equation (1) with robust errors clustered at the canton level. This approach follows previous econometric analytic conventions and best practices for public health policy research (Wing et al., 2018; Wooldridge, 2010). Because we have year fixed effects, we do not need Post2014 as a main effect.

Subsequently, we define Delta $2\left(\Delta 2_{j t}\right)$ as the difference in birth rates for teens (15-19) and adult women in their late 20s (25-29); and Delta $3\left(\Delta 3_{j t}\right)$ as the difference in birth rates for teens $(15-19)$ and adult women in 
their early 30s (30-34), in each canton $j$ in each year $t$. We analyze $\Delta 2_{j t}$ and $\Delta 3_{j t}$ in analogous form as equation (1) and present separate results for each specification with and without time-varying control variables.

An alternative random effects specification using an expanded time-constant covariate vector including proportion Afro-Ecuadorian, literacy level, percentage use for mobile phone, Internet and computer, as well as dummy variables for health insurance and employment, gave similar results. However, a Hausman test strongly rejected the null hypothesis that the random effects model provides consistent estimates $\left[\chi^{2}(10)=140.23\right.$, $\mathrm{p}=0.000]$. Hence, we hereafter present only the fixed effects results. Of note, there is some minor variation on the percentage of women who self-identify as Indigenous. Appendix Figs. A2-A3 show trends for indigenous self-identification for random first and last 18 cantons. Nevertheless, for the 221 cantons during the entire observation period, $96 \%$ of canton observations classified as indigenous for one period remain as indigenous in next period.

For the estimation, we used Stata SE 16.1 xtreg commands with fixed effects (fe) and cluster options. Since the dependent variable is already a difference in birth rates, the coefficient $\alpha^{2}$ already provides a DDD estimator. (Also, we did not implement a Poisson model because the dependent variables can be, and often are, negative numbers, the data are not discrete, and there were no canton-year cells with zero teen births).

\subsection{Tests of Robustness}

Comparable trends assumption. We investigated the comparable trends assumption using visual methods as well as a formal tests using event study models to assess potential effects during the intervention and in the preintervention period (year $<2015)$.

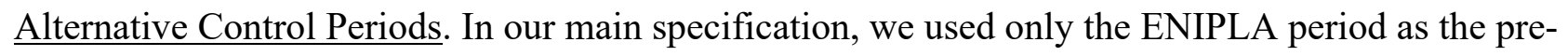
intervention time. To check on alternative pre-intervention periods, we used all of the data in the ENIPLA (2011-2014) and pre-ENIPLA (2007-2010) years, as well only the pre-ENIPLA period. 


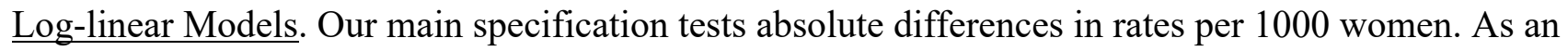
alternative, we ran relative risk models, where the dependent variable $\left(\Delta_{j t}\right)$ was the difference in log birth rates.

Population-Weighted Regressions. In our main specification, all cantons had equal regression weight. As another robustness test, we ran our model as a weighted regression with population weights derived from the 2010 Census data on the percentages of women (ages 15-29) at the canton level (Deb et al., 2017). Weighted regression serves to account for the potentially differential program effects depending on canton size. A population weighting scheme in repeated cross section is akin to inverse probability of selection in a random sampling framework (Ridder and Moffitt, 2007).

Alternative Year of Intervention. The official SRH policy changed abruptly by presidential decree in 2014 (Correa, 2015; Official Register, 2014), and thus we defined the binary variable Post $_{t}$ as equal to 1 if the year is greater than 2014. Since there may have been delays in the switch from ENIPLA to Plan Familia due to inertia or problems with plan implementation, we re-estimated our model with Post $_{t}$ as equal to 1 if the year was greater than 2015 .

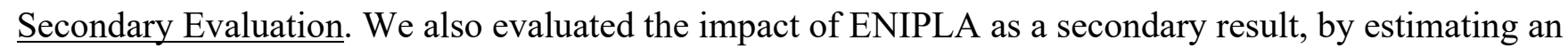
equation similar to (1), but using only the pre-ENIPLA period as pre-intervention, and a Post $2010=1$ as the post intervention dummy for years 2011-2014.

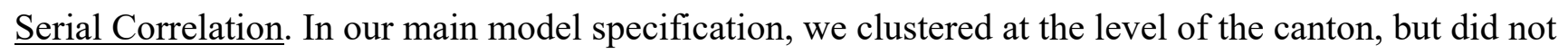
correct for potential serial correlation. As one test of robustness, we re-estimated our model with robust standard errors clustered at the canton level, and serial correlation with a three-period autoregressive, AR(3), correlation matrix. The rationale was the possibility that characteristics at the canton level in one year could affect how policies were implemented in the next three years. We allowed for an autocorrelation process when computing robust standard errors as the number of groups is relatively large (Bertrand et al., 2004).

$\underline{\text { Other robustness tests. }}$ We also checked for alternative specifications of equation 1. 
Lastly, because the indigenous self-identification can change over time (Appendix Figures A2 and A3), we also changed the definition of highly-indigenous canton to be time-invariant based on an average over all of the years (IND2); and then based on quintiles ( canton was in bottom three quintiles).

\subsection{Results}

\subsection{Descriptive Statistics.}

Table 1 presents descriptive statistics for 221 cantons in Ecuador for the 10-year span from 2008 to 2017. The average teen population at the canton level over the decade was 3,374 women aged 15 to 19 years, ranging from 86 in small rural areas to over 120,000 in large cities. The average teen birth rate was 86 per 1000 women (ranging from 6 to 227); while the average young adult (20-24 year) birth rate was 118 per 1000 women (ranging from 19 to 319$)$. The average late 20s (25-29 year) birth rate was 100 per 1000 women (ranging from 18 to 267); while the average early 30s (30-34 year) birth rate was 77 per 1000 women (ranging from 13 to 226). On average, a quarter (25\%) of canton-year observations were classified as having high indigenous concentration (i.e., where more than $12 \%$ of women self-identified as indigenous in that year).

\section{[TABLE 1 ABOUT HERE.]}

\subsection{Analyses of Group Means.}

Figure 2 compares the trends in mean birth rates of teen mothers (black data points) and young adult mothers (grey data points) among 221 cantons. In both teens and young adults, the mean birth rate appears to be declining during the pre-ENIPLA (2008-2010) and ENIPLA (2011-2014) periods, although the rate of decline is more marked in the young adult group. In the Plan Familia (2015-2017) period, the rate for young adult mothers appears to continue to decline through at least 2016, while the rate for teen mothers increases and then remains stagnant. 


\section{[FIGURE 2 ABOUT HERE.]}

Table 2 shows the mean live birth rates per 1000 women for teens (ages 15-19) and young adults (ages 2024). Overall, teen birth rates in cantons with low indigenous concentration were lower in the post period (20152017) (by 8.43 per 1000 women); while young adult birth rates were lower by a greater margin (13.29 per 1000 women). For cantons with high indigenous concentration, that difference was even more pronounced: while the teen birth rate in highly-indigenous cantons decreased by only 4.92 points, it was reduced by over 18 points among young adults. The triple differences (DDD, of teen minus young adult and indigenous minus nonindigenous) was 8.67 per 1000 women, and highly significant $(\mathrm{p}<0.001)$. This implies that birth rates in indigenous cantons have not declined as much as in non-indigenous cantons; and that during the Plan Familia years (2015-2017) the teen births in indigenous cantons have comparatively worsened. The rest of the analysis delves more deeply into this main result by using regression analysis and two additional control groups: women in their late 20s (25-29 years) as well as women in their early 30s (30-34 years).

\subsection{Regression Results.}

Table 3 shows our main regression results based upon a time- and canton-fixed effects model, with robust standard errors clustered at the canton level and using only ENIPLA (2011-2014) as the pre-intervention period. The dependent variable is Delta 1 (difference between teen and young adult birth rates) in columns 1 and 2; Delta 2 (the difference between teen and late 20s birth rates) in columns 3 and 4; and Delta 3 (the difference between teen and late 30s birth rates) in columns 5 and 6 . In column (1), we present the main results, unadjusted for covariates, where the interaction term of Indigenous $\times$ Post is 9 per 1000 women and highly significant $(\mathrm{p}<0.001)$. In column (2), we show the regression results for the same model specification, adjusted for all timevarying control variables. The control variables only slightly reduced the main DDD results to 8.5 per 1000 women and still highly significant. The results for the interaction of interest are very similar when we use the alternative control groups with and without time-varying control variables using Delta 2 and Delta 3 as dependent variables in columns 3-6. 
[TABLE 3 ABOUT HERE.]

The 8.5-point change in the difference over time (2015-2017) between teen and young adult birth rates, and between cantons with low and high indigenous concentrations, is from a baseline mean difference of 31 in 2014. This implies an overall $27 \%(8.5 / 31)$ increase in the birth rate difference for high-indigenousconcentration cantons, most likely affected due to teen females not being able to access contraception services.

Table 4 presents DDD regression results where we re-estimated our models using both the ENIPLA and preENIPLA periods as an alternative pre-intervention period. The coefficients of the interaction of interest are similar to the previous table. The DDD estimates remain highly significant $(p<0.001)$ across the six fixed effects specifications with and without time-varying control variables.

\section{[TABLE 4 ABOUT HERE.]}

\subsection{Other Robustness Tests.}

Figure 3 provides graphical evidence that the trends in birth rate differences for teen and young adults groups in cantons with low and high indigenous concentration were comparable prior to 2015. Specifically, in Figure 3, we plot unadjusted DD estimates by year for low and high indigenous cantons.

\section{[FIGURE 3 ABOUT HERE.]}

Table 5 presents event study models for our three control groups. We re-estimated eq. (1) above as a standard event study with interactions between IND and each year in our dataset $(I N D \times 2008 \ldots I N D \times 2013$; omitted IND $\times 2014$ - the period interaction prior to the Plan Familia intervention; IND $\times 2015$; IND $\times 2016$; and $I N D \times 2017$ ). In addition to reporting the coefficient and standard errors for each of the leads and lags, we also report a test on the joint significance of the leads $(I N D \times 2012$ and $I N D \times 2013)$. The test of joint significance for the leads in model 1 was not significant $[F(2,220)=0.18$; Prob $>F=0.8314]$; nor was it significant for model $2[F(2,220)=0.29 ;$ Prob $>F=0.7505]$. The results were similar for models 5 and 6 . The event study, conditioning on the fixed effects and our time-varying covariates, is a rigorous way to assess the parallel trends 
assumption. We can confirm that the lead effects were insignificant and small and close to 0 in our main models using young adults as comparison group (columns 1 and 2), and for models 5 and 6 (using women in their early 30s as a comparison group). Nevertheless, the joint significance test for the lead effects was significant in models 3 and 4 suggesting that the parallel trends assumption did not fully hold when we used women in their late 20 s as a control group. In addition, the event study models also allow us to assess lags dynamics in the policy response. The main effect presented earlier in Table 3 (as the $I N D \times$ Post interaction) is the effectively the average of the effects, which seem to be mostly present in the $I N D \times 2016$ interaction. That is, the policy seems to have taken about one year to fully have its deleterious effect; and lost its impact by 2017 (which makes sense because Plan Familia was abolished early that year by Presidential decree, from the new President Moreno).

\section{[TABLE 5 ABOUT HERE.]}

Table 6 (columns 1 and 2) presents DDD estimates for the log difference (that is, log teen birth rate log young adult birth rate) model, using robust standard errors in parentheses clustered at canton level. The interaction (DDD) term indicates that teen births in cantons with high indigenous concentration increased by $7 \%$ compared to young adults in low indigenous cantons. The interaction is slightly reduced (to $6.36 \%$ ) when controlling for time-varying covariates. The results for the alternative control groups (in columns 3-6) are slightly larger and remain stable in the range of 6 to $9 \%$.

\section{[TABLE 6 ABOUT HERE.]}

Table 7 shows weighted regression results, with weights based on the 2010 Census data percentages of women (ages 15-29) at the canton level. The main interaction terms are again positive and significant though the magnitudes, particularly when using time-varying control variables, are lower. In the unadjusted model in column (1), the interaction term of indigenous $\times$ post is 8.1 per 1000 women and highly significant $(p<0.001)$. The coefficient in the adjusted model in column (2) is 4.6 per 1000 women and also significant $(p<0.01)$. In the other differences models (columns 3-6), the interaction terms indicate that teen births in cantons with high 
indigenous concentration increased also; except the model in column (4) comparing teen birth rates with those of women in their late $20 \mathrm{~s}$. The weighted regression results are attenuated compared to the main results, which makes sense because higher indigenous concentration cantons tend to be smaller in population.

\section{[TABLE 7 ABOUT HERE.]}

Table 8 presents DDD regression results where we use a dummy indicator for Post such that Post=1 if the year is greater than 2015 (instead of greater than 2014). The DDD coefficients are larger than in the main results table: 11.47 unadjusted and 11.18 adjusted for time-varying control variables. The main DDD estimates, for the two additional control groups unadjusted and adjusted (columns 3-6) are smaller in magnitude but remain significant. Since the effects are stronger in the post 2015 models (compared to the main results), we can infer that the impact was concentrated in the 2016-17 period.

\section{[TABLE 8 ABOUT HERE.]}

Table 9 presents DDD regression results where we re-estimated our models without the ENIPLA period, and thus using only the pre-ENIPLA period as an alternative pre-intervention period. The coefficients of the interaction of interest are generally strengthened compared to the main results. The DDD estimates remain significant across the six fixed-effects specifications with and without time-varying control variables.

\section{[TABLE 9 ABOUT HERE.]}

Table 10 presents the results for the secondary result evaluating the impact of ENIPLA using Delta 1 (difference between teen and young adult birth rates). In column (1), we present unadjusted results, and the relevant interaction term of indigenous $\times$ post is 3.7 per 1000 women but not significant. In column (2) we show the adjusted regression results; the covariates reduce the DDD coefficient results: the critical interaction term of indigenous $\times$ post is 2.8 per 1000 women and still not significant. These results suggest that ENIPLA did not affect birth rates for teen women in high indigenous cantons as Plan Familia did.

[TABLE 10 ABOUT HERE.] 
Appendix Table A2 shows DDD regression results clustered at the canton level, and correcting for threeperiod serial autocorrelation, $\mathrm{AR}(3)$. The DDD coefficients of the main interaction are slightly decreased from previous tables (now in the 5-7 per 1000 range), yet remain highly significant $(\mathrm{p}<0.001)$.

Appendix Table A3 shows results of an alternative specification of equation 1 where the dependent variable is the teen birth rate $(T R)$ and the comparison group birth rate $(C R)$ is included as a control variable as follows:

$$
T R_{j t}=\beta^{1} C R_{j t}+\beta^{2} I N D_{j}+\beta^{3} I N D_{j} \times \text { Post }_{t}+\boldsymbol{\beta}_{t}^{4}+\boldsymbol{\beta}_{j}^{5}+\boldsymbol{\beta}^{6} Z_{j}+v_{j t}
$$

This specification ensures an unrestricted $\beta^{0}$ coefficient (rather than assume $\alpha^{0}=1$, as it was done under the main specification in equation 1). Appendix Table A3 presents fixed effects with unrestricted models using each comparison group. Columns (1) and (2) use young adults as the comparison group; columns (3) and (4) use women in their late20s and comparison group; and columns (5) and (6) use women in their early30s as comparators. In column (2), our preferred specification, the interaction term of IND $\times$ Post is 5.3 per 1000 women and highly significant $(\mathrm{p}<0.001)$. In other model specifications, the interaction term of interest remains highly significant and positive (in the range of 3.8 to 5 per 1000 women).

Appendix Table A4 shows the results of changing the definition for highly-indigenous cantón so that it is time-invariant. Under the ind2 time-invariant definition, a cantón is classified as high indigenous if the percentage of women who self-identified as indigenous across all years (2008-2017) is above the national mean $(>12 \%)$; low indigenous if that percentage is at or below the national mean $(\leq 12 \%)$ across all years. In column (2), our preferred specification, the interaction term of ind $2 \times$ Post is 8.5 per 1000 women and highly significant $(p<0.001)$. In other model specifications, the interaction term of interest remains highly significant and positive (in the range of 7.3 to 9.7 per 1000 women). Under this re-definition, once a canton was defined as "highly indigenous" it stayed that way over the entire sample period, and the main effect of Indigenous $>12 \%$ dropped out of the model since it was captured by our canton fixed effects.

Appendix Table A5 shows the results of changing the definition for highly-indigenous cantón so that it is based on quintiles. Under the ind3 time-invariant definition, a cantón is classified as high indigenous if the 
percentage of women who self-identified as indigenous is in the top two quintiles of the national distribution across all years (2008-2017); and low indigenous if that percentage is in the bottom three quintiles of the national distribution across all years. In column (2), our preferred specification, the interaction term of ind $3 \times$ Post is 6.6 per 1000 women and highly significant $(\mathrm{p}<0.001)$. In other model specifications, the interaction term of interest remains highly significant and positive (in the range of 5.5 to 8.7 per 1000 women). Our results are robust to alternate definitions of highly indigenous share cantons (other than just using the national mean of $12 \%$ as a cutoff) including upper two quintiles versus bottom three.

\section{Potential mechanisms}

The evidence suggests that Plan Familia increased adolescent birth rates by influencing SRH service providers. The effect is concentrated in cantons where more women self-identify as indigenous, so racial/ethnic and socio-economic disparities as well as decreased access to healthcare services appear to play a key role (Anderson et al., 2016). To analyze the potential mechanisms more closely, we return to the last two nationally representative surveys, ENSANUT 2012 and 2018, and look at the triple differences, not only comparing teens and young adults as we did at the beginning to motivate the research, but also including an indicator on indigenous race/ethnicity self-identification. Appendix Table A6, column (1) shows a strong (negative) and significant DDD interaction for any contraception use ever; the DDD interaction in column (2), for any contraception used currently now (i.e., in 2018), was still negative but lost its significance. These results are congruent with our hypothesis because Plan Familia was abolished by 2017; thus it makes sense to see an effect in the "ever" utilization variable only, and not necessarily in the current or "now" variable for 2018.

These empirical results are consistent with various theoretical interpretations. As alluded, the program can be understood in the context of a political trade-off between choosing what is better for population health versus what is best for a politician's own private benefit (Barro, 1973; Rivas, 2016). On the one hand, choices that enhance the health and living standards of citizens can improve the politician's chances of re-election. On the other hand, the politician may be tempted instead to make choices that serve his own private benefits or 
beliefs. In this framework, Plan Familia increased the cost to adolescent women, particularly in cantons with higher indigenous concentration, in terms of higher adolescent birth rates, while the SRH policies were suddenly shifted to be more in line with the private beliefs of the president and the Plan's director. As in other cases where access to contraception is restricted, the birth rates consequently increase. This interpretation of the program leaves unanswered, however, precisely how the program might have reduced contraception access for teenage women. Contraception services should be available, by law, at each level of MOH health services provision. The canton with the smallest population in 2015 had 2354 inhabitants; and for every 2000 inhabitants, there should be a type-A health center (Salcedo et al., 2014) [pg. 48]. Similarly, the law established that at each health center, there should be access to contraception, including at the lowest level of health services provision (Bucheli et al., 2014). Since clinics were not closed, the most likely explanation for how Plan Familia limited access to contraception for teens was by altering the environment and the "adolescent friendliness" of the SRH clinics and health posts.

In particular, the program seems to have acted as a top-down coordination mechanism to make contraception access for teens less socially acceptable or less desirable, making it harder for adolescent females to demand access to-and information about-contraception. This top-down presidential decree and official guidelines made SRH harder to access for adolescents, and consequently the young adults' birth rate rates were decreasing faster than the teens' birth rates. Indeed, this interpretation is supported by anecdotal evidence, such as the comments by the president and the Plan Familia director. The president openly decried his own former ENIPLA policies as "abortionist and gay" (E1 Universo, 2015a); and the director of Plan Familia stated that "we will very much emphasize abstinence" (El Universo, 2015b). Furthermore, the Plan Familia director, stated that adolescents when they go to health centers should be questioned: "Are you sure that when you start your sexual life as adolescent you are not curtailing your dreams? your medium and long term plans?" (E1 Universo, 2015b). Moreover, the information campaign "Habla serio: sexualidad sin misterios" [All joking aside: sexuality without mystery] (See Figure 1) was stopped; including radio, TV, and the site www.sexualidadsinmisterios.com were taken down in favor of promotion of abstinence, delay of sexual 
initiation and the Billings method (El Universo, 2015c). The fundamental problem, particularly in the rural areas, is that adolescents have not had access to contraception, not even basic information, so that their conduct is highly dependent on how policies are actually implemented (Nicolalde-Escobar, 2016).

\section{Discussion and Conclusion}

We analyzed canton-level birth rate data for women ages 15-24 in Ecuador during 2008-2017. By looking at a sudden, unanticipated policy change from ENIPLA to Plan Familia, we identified the effect of implementing more restrictive access to sexual and reproductive health resources on adolescent women. Utilizing a differencein-differences approach, we determined how the difference in the birth rates between adolescent (15-19 years) and young adult (20-24) women changed after the switch to Plan Familia. Further utilizing a triple-difference approach, we determined how this difference in birth rates varied among cantons with low and high proportions of indigenous women. Our results suggest that the dismantling of ENIPLA and the subsequent reduction of differentiated, adolescent-friendly SRH services after 2014 significantly increased teen birth rates in comparison to young adult birth rates, particularly among indigenous women. That is, we demonstrate that Plan Familia disproportionately affected teen birth rates in cantons with higher indigenous concentrations. We estimate that the Plan Familia intervention effect in cantons with high indigenous concentration is to have increased teen birth rates by $27 \%$ over three years (so about $9 \%$ per year) over the baseline mean difference (between teens and young adults) in 2014. The results were qualitatively similar when we using comparison birth rates for women in their late 20 s or in their early 30 s as alternative control groups.

A number of robustness checks provide reassurance for the main results. First, there is visual and formal evidence that the pre trends were comparable. Young adult women (aged 20-24) are an adequate control for teen women (aged 15-19) because the fertility trends for the two groups were comparable, and the policy shock clearly targeted teens only: dismantling ENIPLA meant curtailing access to information and adolescent-friendly health services. Second, the main results cannot be simply an artefact of the years of observation. Instead of using only ENIPLA as pre-intervention period, we also conducted DDD analyses using both ENIPLA and pre- 
ENIPLA as pre-intervention periods. Similarly, we also used pre-ENIPLA only as the pre-intervention period. Third, by using post $>2015$ in a robustness test, we rule out the possibility that the main findings in the DDD models are driven solely by births in 2015 , a year that could have been only partially affected by the switch to Plan Familia. Fourth, our results are robust to potential issues with small cantons: there were no cantons with zero births, yet the high indigenous cantons tend to be smaller. When we used population-based weights, the results are attenuated but still significant. Furthermore, other changes such as changing the comparison group (to women in their late 20s, or in their early 30s), specification to logarithmic differences, definition of indigenous concentration, or serial correlation corrections still supported our primary conclusion: the DDD coefficient, the critical interaction, was in the hypothesized direction and significant in 63 out of 66 specifications across all models presented in Tables 3-9 and Appendix Tables A2-A5. Finally, our secondary result, evaluating ENIPLA, suggests that the earlier policies did not reduce teen birth rates (as the government claimed). Yet the main interaction, the DDD result, was not significant, meaning that ENIPLA did not comparatively increase teen birth rates in indigenous cantons, as Plan Familia did.

Given the importance of the topic and policies that our paper is addressing, the latter point deserves further discussion and framing. ENIPLA did not (relatively) reduce adolescent pregnancies in highly indigenous cantons. The interaction result was nil. That on itself, however, is not a totally undesirable outcome because it means it had no differential effect based on race/ethnicity (i.e., no discrimination). Plan Familia, on the other hand, did have a differential effect based on race/ethnicity (so it was discriminatory) because it reduced access in indigenous cantons and thus increased birth rates in highly-indigenous cantons vs low-indigenous cantons.

Finally, it is important to note also that teens in even low-indigenous cantons may be potentially impacted that is, the control group is not a pure control group in that sense, that our third difference is along the lines of a dose-response check. Thus, our original hypothesis was to expect larger effects in cantons with a higher share of indigenous population relative those with a lower share. Yet, in fact, what we see is more of an inverted-U effect based on the quintile-based definition of highly-indigenous cantons (Appendix Table A5). Hence, more 
analysis is needed to uncover all of the complexities in the interaction of race/ethnicity and access to SRH services.

The results overall, nevertheless, constitute a test of abstinence only and "family-values" policies implemented from the top leadership at the national level. In terms of proximate channels of operation, the less adolescent-friendly policies were instituted in the context of a sudden policy reversal. As mentioned, the president decried his own past policies as "abortionist and gay" (El Universo, 2015a); the head of the family planning program stated that Plan Familia "will very much emphasize abstinence" (El Universo, 2015b); and evidence-based information on contraception for adolescents was intentionally restricted (El Universo, 2015c). Nevertheless, the root mechanisms may be the underlying inequity in a health system that curtails access to basic health services in general, and sexual/reproductive health services in particular for indigenous women. One study of in the Ecuadorian Amazon basin found that most pregnancies among indigenous women were unintended (62.7\%); over two-thirds (73.7\%) reported having had at least one unintended pregnancy; and being young, single, and indigenous were significant risk factors for unintended pregnancy, in addition to having low access to education and having more than two children (Goicolea and Sebastian, 2010). Another study in six communities from the central highland region of Ecuador found that most indigenous women work long hours (about 14 hours per day), largely on agricultural production and food preparation, though other tasks required considerable time as well: washing and drying clothes, fetching firewood and water for cooking, and child care. Moreover, they give birth while they are still in their teens. The average age for first pregnancy is 19 years (range 14-29). About a fifth (17\%) had problems accessing health services, and most (58.1\%) preferred traditional health services, particularly in pregnancy and childbirth, while only $16.1 \%$ preferred public health services (Waters et al., 2018).

It is instructive to compare the impact of the Plan Familia policy with other studies although, as mentioned, most studies are U.S.-based, so the comparisons are limited. In the U.S., income-based Medicaid family planning expansions reduced teen birth rates by 5.3\%; while a 5-point rise in unemployment would lead to a 3\% reduction in teen childbearing, representing $16 \%$ of the $19.3 \%$ observed decline in teen childbearing rates 
(Kearney and Levine, 2015). Similarly, reducing funding for family planning funding by 67\% in Texas increased teen birth rates by 3.4\% over four years (Packham, 2017). Moreover, legalization of abortion in the 1970s in the U.S. changed the composition of women at risk of becoming unmarried mothers some 15-24 years later. That composition effect reduced out-of-wedlock teen birth rates by $6 \%$, which accounted for about $25 \%$ of the observed decline in unmarried teen birth rates over that period (Donohue et al., 2009). Some of these policies have comparable effects to the $27 \%$ increase over three years (that is, about $9 \%$ per year) in the difference between teen and young adult birth rates caused by Plan Familia that we found when comparing cantons with and without high indigenous concentration.

The results also constitute a commentary on the chasm between the rhetoric of electoral candidates and elected politicians and the policies that are actually implemented. The high cost of this divergence tends to be borne by the most vulnerable. This commentary is particularly relevant to Latin American countries, many of which have a long history of populism (Edwards, 2019). Despite the socialist rhetoric of Hugo Chavez in Venezuela, his administration actually fragmented and weakened organized labor, restricted collective bargaining, and undermined vulnerable workers in cooperatives (Posner, 2016). The governments of Correa (in Ecuador) and Chavez (in Venezuela) both engaged in strong pro-poor rhetoric (Ellner, 2012). Yet rhetoric alone does not necessarily ensure that the policies implemented are in fact pro-poor or pro-minorities.

Our research is not without limitations. First, we analyzed rates rather than individual-level data. In particular, we computed birth rates at the finest level of data aggregation, that is, the canton. We reasoned that the quantity and intensity of teen-friendly SRH services at health canters varied across cantons. However, there is no accurate data for when some of the clinics restricted some SRH services to adolescents in predominantly indigenous cantons. Nor is there accurate data about the number of clinics that provided adolescent-friendly services. Second, unlike most U.S.-based studies that rely on state- or county-level variation for identification, we cannot implement such a research strategy in Ecuador, where laws are applied uniformly at the national level. Thus, we need the difference in birth rates (teen - comparison group) for identification. A third limitation is the lack of microdata for additional outcomes such as abortions or sexually transmitted disease prevalence. 
Abortion is illegal in Ecuador-even in cases of rape (Reuters, 2019), and data vary from un-reported to substantially under-reported. Lastly, our identification strategy relies on the assumption that the policy change was an abrupt, unexpected shock. Although we have no reason to believe that adolescents would pre-emptively change their behaviors in anticipation of a policy change, the implementation of a national-level re-structuring of SRH policy can take time. Still, to the extent that more liberal adolescent health policies continued in some cantons after 2015, our results would be biased towards the null.

More research on SRH policies is needed outside of the United States. Randomized controlled trials in low- and middle-income countries (LMICs) may have high internal validity, but they may be less generalizable, more expensive, and not always ethically acceptable. Other rigorous, non-experimental approaches can be implemented in LMICs where there are reasonably complete data sources (as we found in Ecuador) and where sudden and unexpected policy changes or other natural experiments that can be exploited for identification.

In conclusion, the main contribution of this paper is to assess the effects of restrictive SRH policies on adolescent women. The results provide evidence to suggest that restrictive policies, including family-centered, abstinence-only policies, have comparatively increased the rates of teen pregnancy in Ecuador, particularly among indigenous women. 


\section{FIGURES}

\section{Figure 1}

ENIPLA Pamphlet Encouraging Condom Use among Adolescents.

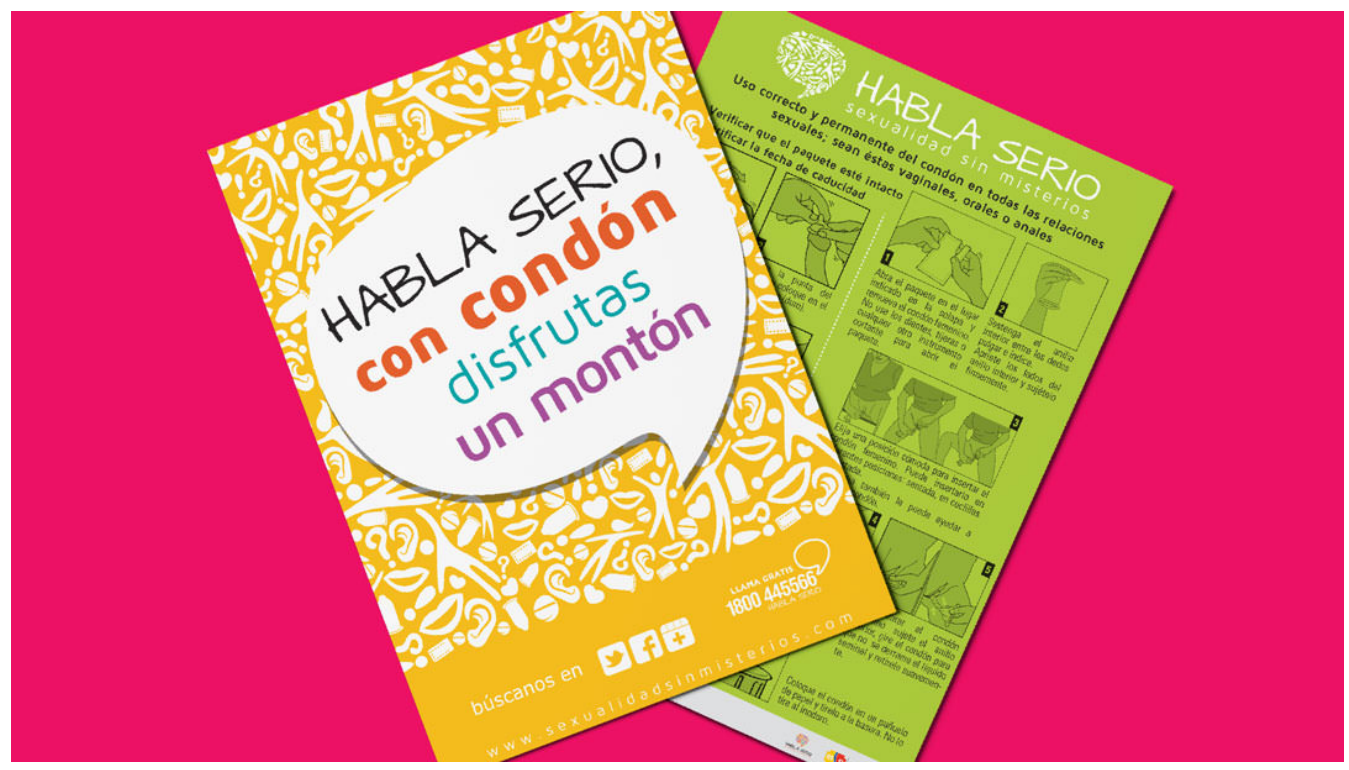

Notes: The campaign slogan "Habla serio," which literally means "Talk seriously," was regularly used in informal conversation as the equivalent of the English "All joking aside." The front page continues "With a condom, you enjoy a lot." The second page describes the "Correct, permanent use of the condom in all sexual relations, whether vaginal, oral or anal." 


\section{Figure 2}

Birth Rates at the Canton level for Teens (15-19) and Young Adults (20-24).

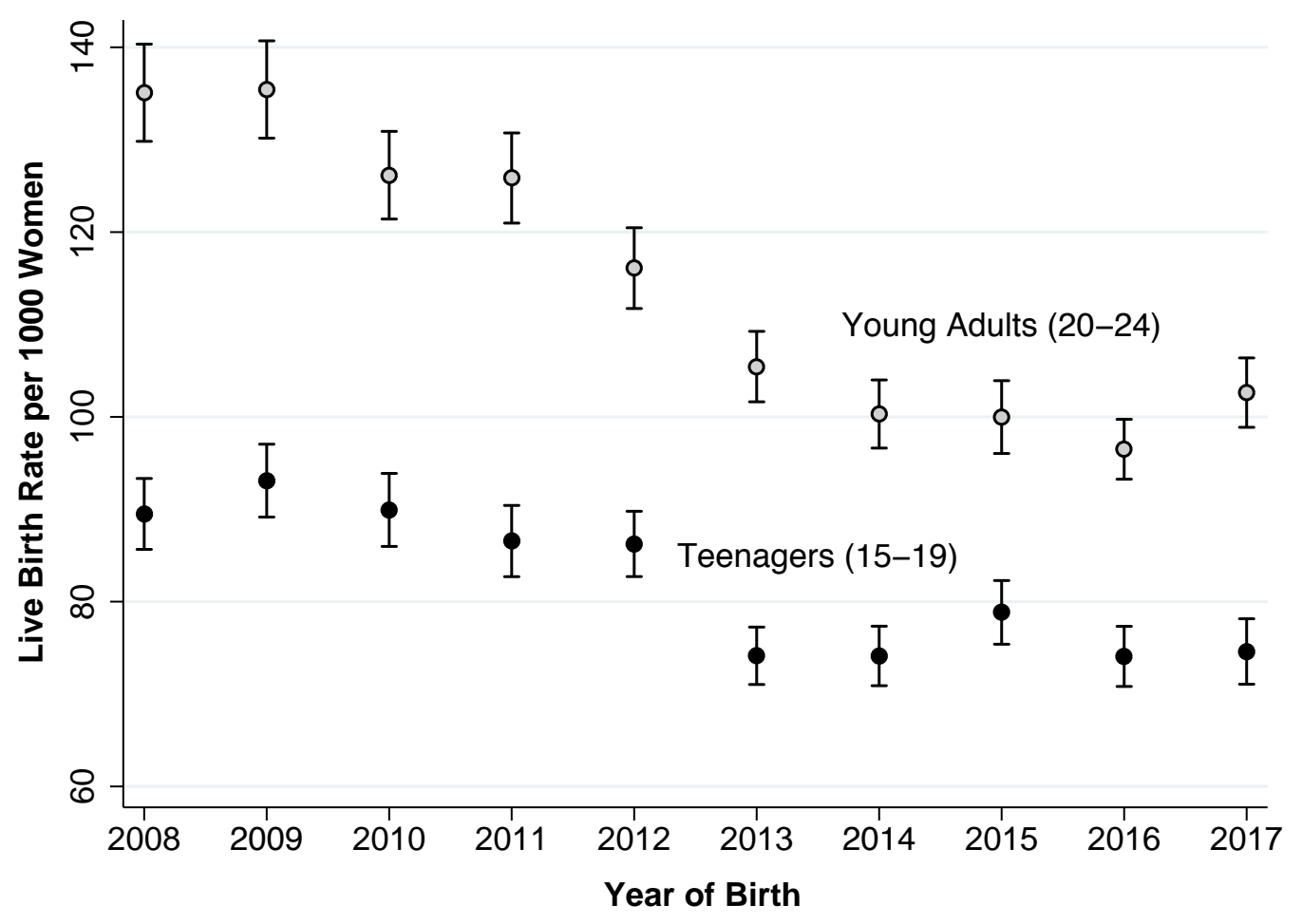

Sources: Ecuador's National Registries of Live Births for 2008-2017; National Census and population projections.

Notes: Each data point represents the unweighted mean birth rate among 221 cantones. The error bars indicate the $95 \%$ confidence interval (that is, \pm 1.96 standard errors) around each mean value. 


\section{Figure 3}

Birth Rate Difference at the Canton Level for Teens (15-19) minus Young Adults (20-24).

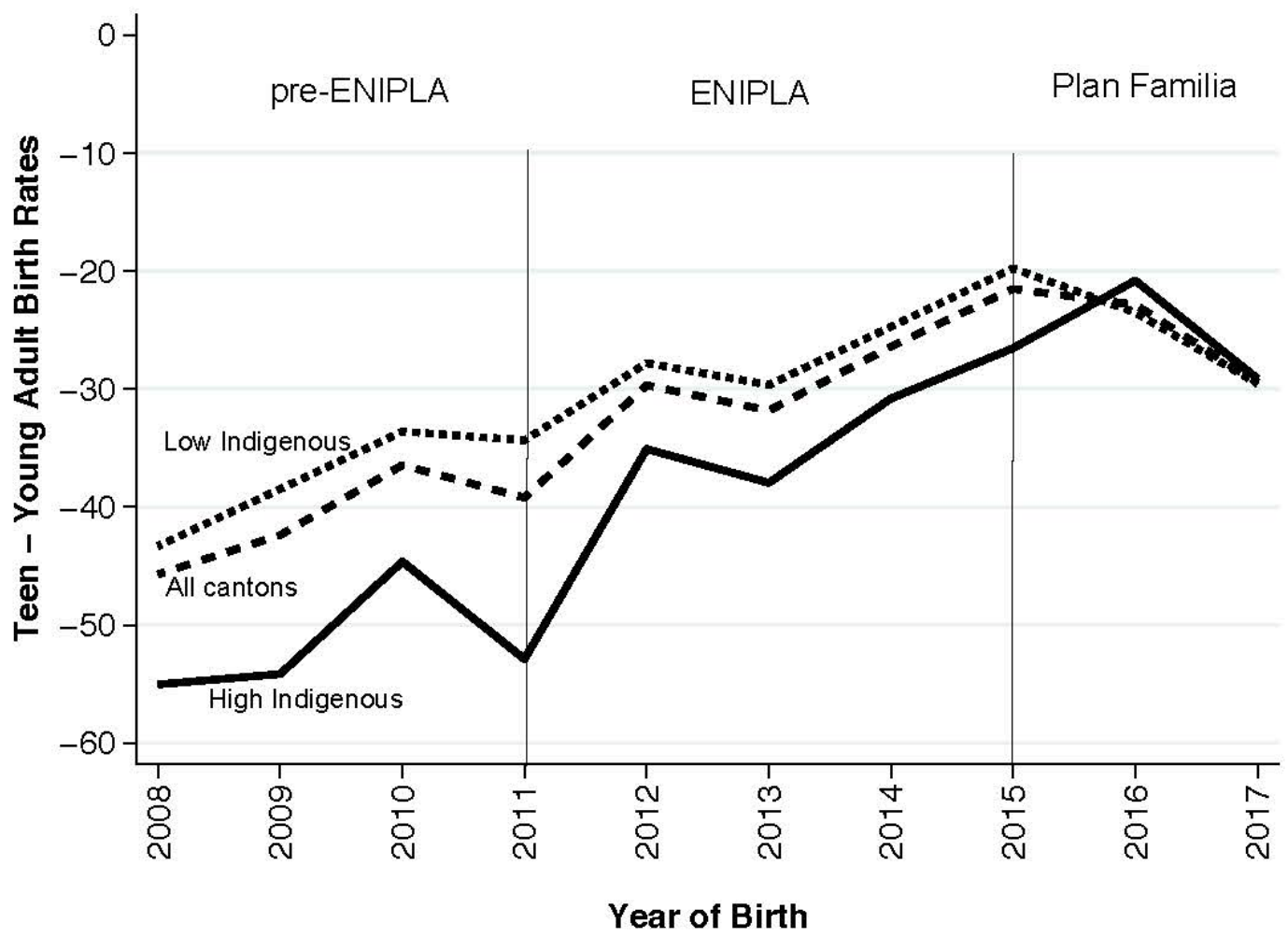

Sources: Ecuador's National Registries of Live Births for 2008-2017; National Census and population projections.

Notes: Each line represents the unweighted mean birth rates among 221 cantones. High indigenous concentration is an indicator variable $=1$ if more than $12 \%$ of women self-identify as indigenous in a given canton for a given year. 
Table 1

Summary Statistics for 221 Cantons: Means for 2008-2017.

Variable

Demographic variables

Female teen population (15-19 yrs.)

Female young adult population (20-24 yrs.)

Female adult late20s population (25-29 yrs.)

Female adult early30s population (25-29 yrs.)

Teen birthrate

Young adult birthrate

Adult late20s birthrate

Adult early30s birthrate

Main outcomes: birth rate differences

Delta1 (teen - young adult)

Delta2 (teen - late20s)

Delta3 (teen - early30s)

Exposures

Year of Birth

Post 2014

Pre 2011

High indigenous concentration ${ }^{\S}$

Time-varying control variables

Teen indigenous rate

Teen average age

Teen average educational level ${ }^{€}$

Teen married/in-union rate

Teen institutional delivery rate

Teen skilled birth attendant rate

Teen at-least-one-prenatal-control rate
Obs.

Mean

Std. Dev

221

2210

2210

2210

2210

100.0

76.8

$-32.6$

24.3

$-145.2$

67.2

2210

$-14.4$

26.5

$-128.8$

87.9

2210

8.7

29.0

$-94.7$

116.4

2210

2012.5

2.87

2008

2017

2210

0.30

0.46

0

0.46

0

0.43

0.25

0.13

0.23

0.23

17.5

0.70

3.58

0.21

0.52

0.82

0.20

0.85

0.19

0.86

0.17

0.20

0.08

0.20

Sources: Ecuador's National Registries of Live Births for 2008-2017; National Census and population projec
Notes: Table presents averages at the canton level for the entire observation period 2008-2017 (inclusive)

"Birth rates are per 1000 women (in the respective age group). $\S$ High indigenous concentration is an indicator variable $=1$ if more than $12 \%$ of women self-identify as indigenous. ${ }^{€}$ Educational levels are: $0=$ none, $1=$ literacy center, $2=$ kinder garden, $3=$ primary, $4=$ basic, $5=$ junior high school, $6=$ high school, $7=$ post secondary, $8=$ university, $9=$ post graduate. 
Table 2

Live Birth Rates by Age Group and Indigenous Status, Ecuador: 2011-2017.

\begin{tabular}{lccc} 
Group & $2011-14$ & $2015-17$ & Difference \\
\hline LOW INDIGENOUS & & & \\
Teen (15-19 yrs.) & 80.34 & 71.92 & -8.43 \\
& 1.05 & 1.03 & -13.29 \\
Young adult (20-24 yrs.) & 109.50 & 96.21 & \\
HIGH INDIGENOUS & 1.17 & 1.12 & -4.92 \\
Teen (15-19 yrs.) & 102.35 & 97.44 & -18.45 \\
& 2.26 & 2.85 & \\
Young adult (20-24 yrs.) & 141.45 & 123.00 & \\
& 2.90 & 3.32 & 4.86 \\
DELTA 1 & & & 13.54 \\
Teens - Young adults & -29.16 & -24.29 & \\
Low Indigenous & 0.75 & 0.81 & $\mathbf{8 . 6 7}$ \\
High Indigenous & -39.10 & -25.56 & $\mathbf{( 2 . 5})^{* * *}$ \\
\hline
\end{tabular}

Sources: Ecuador's National Registries of Live Births for 2008-2017; National Census and population projections. Notes: Table presents canton-level birth rates per 1000 women with standard errors in parentheses.

Cantons are classified as having high indigenous concentration if more than $12 \%$ of women self-identify as indigenous in that year; and low indigenous concentration if $12 \%$ or fewer women self-identify as indigenous. The $12 \%$ cutoff was chosen because it is the national mean.

DDD denotes triple difference.

$* * *$ significant at $\mathrm{p}<0.001$ 
Table 3

Effect of Abrupt Change in Sexual and Reproductive Health Policy on Adolescent Birth Rates in Ecuador 2011-2017: Triple Difference Main Regression Results Using ENIPLA (2011-2014) as Pre-Treatment Period.

\begin{tabular}{|c|c|c|c|c|c|c|}
\hline & (1) & (2) & (3) & (4) & (5) & (6) \\
\hline & $\begin{array}{l}\text { Delta1 } \\
\text { (teen - } \\
\text { young } \\
\text { adult) }\end{array}$ & $\begin{array}{l}\text { Delta1 } \\
\text { (teen - } \\
\text { young } \\
\text { adult) }\end{array}$ & $\begin{array}{c}\text { Delta2 } \\
\text { (teen - } \\
\text { late20s) }\end{array}$ & $\begin{array}{c}\text { Delta2 } \\
\text { (teen - } \\
\text { late20s) }\end{array}$ & $\begin{array}{c}\text { Delta3 } \\
\text { (teen - } \\
\text { early30s) }\end{array}$ & $\begin{array}{c}\text { Delta3 } \\
\text { (teen - } \\
\text { early30s) }\end{array}$ \\
\hline Indigenous $>12 \%=1$ & $\begin{array}{c}-5.088 \\
(5.214)\end{array}$ & $\begin{array}{l}-5.312 \\
(5.210)\end{array}$ & $\begin{array}{l}-4.213 \\
(3.879)\end{array}$ & $\begin{array}{l}-2.050 \\
(4.024)\end{array}$ & $\begin{array}{c}0.273 \\
(4.672)\end{array}$ & $\begin{array}{c}1.016 \\
(4.467)\end{array}$ \\
\hline Indigenous $>12 \%=1 \times$ Post $2014=1$ & $\begin{array}{c}9.004 * * * \\
(2.282)\end{array}$ & $\begin{array}{c}8.538 * * * \\
(2.304)\end{array}$ & $\begin{array}{c}9.563 * * * \\
(2.742)\end{array}$ & $\begin{array}{l}7.910 * * \\
(2.990)\end{array}$ & $\begin{array}{c}7.533 * * * \\
(2.065)\end{array}$ & $\begin{array}{c}8.547 * * * \\
(2.346)\end{array}$ \\
\hline Canton fixed effects & YES & YES & YES & YES & YES & YES \\
\hline Year fixed effects & YES & YES & YES & YES & YES & YES \\
\hline Time-varying control variables & NO & YES & NO & YES & NO & YES \\
\hline Observations & 1547 & 1547 & 1547 & 1547 & 1547 & 1547 \\
\hline
\end{tabular}

Sources: Ecuador's National Registries of Live Births for 2008-2017; National Census and population projections.

Notes: Table presents fixed effects main regression results.

Interaction term represents triple differences (DDD) in birth rates per 1000 women:

Delta 1 is for (teens - young adults)

Delta 2 is for (teens - late 20s)

Delta 3 is for (teens - early 30 s)

Robust standard errors in parentheses clustered at canton level:

$* \mathrm{p}<0.05 * * \mathrm{p}<0.01 * * * \mathrm{p}<0.001$

Cantón is classified as high indigenous if percentage of women who self-identified as indigenous is above the national mean ( $>12 \%)$; low indigenous if that percentage is at or below the national mean $(\leq 12 \%)$.

Post 2014 is a dummy variable $=1$ if year $>2014$. Because we have year fixed effects, we do not need Post2014 as a main effect.

Time-varying control variables include cantón-level means for: age, education, proportion Indigenous, married/in-union, institutional delivery, skill birth attendance, any prenatal control, and second-or-higher-order birth. 
Table 4

Effect of Abrupt Change in Sexual and Reproductive Health Policy on Adolescent Birth Rates in Ecuador 2008-2017: Triple Difference Regression Results Using ENIPLA and pre-ENIPLA as Pre-Treatment Periods.

\begin{tabular}{|c|c|c|c|c|c|c|}
\hline & $\begin{array}{c}(1) \\
\text { Delta1 } \\
\text { (teen - } \\
\text { young } \\
\text { adult) } \\
\end{array}$ & $\begin{array}{c}(2) \\
\text { Delta1 } \\
\text { (teen - } \\
\text { young } \\
\text { adult) } \\
\end{array}$ & $\begin{array}{c}(3) \\
\text { Delta2 } \\
\text { (teen - } \\
\text { late20s) } \\
\end{array}$ & $\begin{array}{c}(4) \\
\text { Delta2 } \\
\text { (teen - } \\
\text { late20s) }\end{array}$ & $\begin{array}{c}(5) \\
\text { Delta3 } \\
\text { (teen - } \\
\text { early30s) }\end{array}$ & $\begin{array}{c}\text { Delta3 } \\
\text { (teen - } \\
\text { early30s) } \\
\end{array}$ \\
\hline Indigenous $>12 \%=1$ & $\begin{array}{l}-0.176 \\
(4.325)\end{array}$ & $\begin{array}{l}-0.993 \\
(4.227)\end{array}$ & $\begin{array}{c}1.970 \\
(3.530)\end{array}$ & $\begin{array}{c}2.422 \\
(3.638)\end{array}$ & $\begin{array}{c}3.155 \\
(3.291)\end{array}$ & $\begin{array}{c}3.061 \\
(3.577)\end{array}$ \\
\hline Indigenous $>12 \%=1 \times$ Post $2014=1$ & $\begin{array}{c}10.65 * * * \\
(2.756)\end{array}$ & $\begin{array}{c}8.945 * * * \\
(2.624)\end{array}$ & $\begin{array}{c}12.97 * * * \\
(3.248)\end{array}$ & $\begin{array}{c}11.19 * * * \\
(3.212)\end{array}$ & $\begin{array}{c}11.11 * * * \\
(2.504)\end{array}$ & $\begin{array}{c}10.28 * * * \\
(2.493)\end{array}$ \\
\hline Canton fixed effects & YES & YES & YES & YES & YES & YES \\
\hline Year fixed effects & YES & YES & YES & YES & YES & YES \\
\hline Time-varying control variables & NO & YES & NO & YES & NO & YES \\
\hline Observations & 2210 & 2210 & 2210 & 2210 & 2210 & 2210 \\
\hline
\end{tabular}

Sources: Ecuador's National Registries of Live Births for 2008-2017; National Census and population projections.

Notes: Table presents fixed effects regression results.

Interaction term represents triple differences (DDD) in birth rates per 1000 women:

Delta 1 is for (teens - young adults)

Delta 2 is for (teens - late 20s)

Delta 3 is for (teens - early 30 s)

Robust standard errors in parentheses clustered at canton level:

$* \mathrm{p}<0.05 * * \mathrm{p}<0.01 * * * \mathrm{p}<0.001$

Cantón is classified as high indigenous if percentage of women who self-identified as Indigenous is above the national mean ( $>12 \%)$; low indigenous if that percentage is at or below the national mean $(\leq 12 \%)$.

Post 2014 is a dummy variable $=1$ if year $>2014$. Because we have year fixed effects, we do not need Post 2014 as a main effect.

Time-varying control variables include cantón-level means for: age, education, proportion Indigenous, married/in-union, institutional delivery, skill birth attendance, any prenatal control, and second-or-higher-order birth. 
Table 5

Estimated policy effects in the years before and during Plan Familia: 2008-2017.

(1) (2) (3)

(4)

(5)

(6)

Delta1 (teen - Delta1 (teen - Delta2 (teen Delta2 (teen Delta3 (teen Delta3 (teen

\begin{tabular}{|c|c|c|c|c|c|c|}
\hline & young adult) & young adult) & - late20s) & - late20s) & - early30s) & - early30s) \\
\hline \multirow[t]{2}{*}{ Indigenous $>12 \%$} & 5.730 & 4.130 & $14.29 * *$ & $14.74 * *$ & $11.00^{*}$ & $11.44^{*}$ \\
\hline & $(5.171)$ & $(5.513)$ & $(4.403)$ & $(4.914)$ & (4.489) & $(4.775)$ \\
\hline \multirow[t]{2}{*}{2008} & $-17.25^{* * *}$ & $-14.89 * * *$ & $-4.295^{*}$ & -4.977 & $4.929^{*}$ & 3.814 \\
\hline & $(2.111)$ & $(3.215)$ & $(1.755)$ & $(2.762)$ & $(2.013)$ & $(2.764)$ \\
\hline \multirow[t]{2}{*}{2009} & $-13.03 * * *$ & $-10.04 * * *$ & 0.943 & 2.425 & $9.811 * * *$ & $9.796 * * *$ \\
\hline & $(1.739)$ & $(2.001)$ & $(1.820)$ & $(2.085)$ & $(1.901)$ & $(2.161)$ \\
\hline \multirow[t]{2}{*}{2010} & $-8.556^{* * *}$ & $-5.404 * *$ & 1.685 & 3.551 & $9.191 * * *$ & $9.804 * * *$ \\
\hline & $(1.732)$ & $(1.956)$ & $(1.869)$ & $(2.086)$ & $(1.920)$ & $(2.068)$ \\
\hline \multirow[t]{2}{*}{2011} & $-9.208 * * *$ & $-4.710^{*}$ & -0.00615 & 2.701 & $6.871 * * *$ & $8.569 * * *$ \\
\hline & $(1.610)$ & $(2.214)$ & $(1.714)$ & $(2.357)$ & $(1.551)$ & $(2.045)$ \\
\hline \multirow[t]{2}{*}{2012} & -2.695 & 3.493 & 2.185 & 6.036 & $5.565 * * *$ & $8.542 * *$ \\
\hline & $(1.653)$ & $(3.211)$ & $(1.510)$ & (3.299) & $(1.663)$ & $(3.066)$ \\
\hline \multirow[t]{2}{*}{2013} & $-4.819 * *$ & -2.687 & -0.861 & 0.543 & 1.245 & 2.071 \\
\hline & $(1.642)$ & (1.786) & (1.669) & $(1.878)$ & $(1.655)$ & $(1.814)$ \\
\hline \multirow[t]{2}{*}{2015} & $5.277 * *$ & 2.539 & $3.558^{*}$ & 1.759 & $5.860 * * *$ & $4.878^{* *}$ \\
\hline & (1.719) & $(1.858)$ & $(1.581)$ & $(1.681)$ & $(1.469)$ & $(1.741)$ \\
\hline \multirow[t]{2}{*}{2016} & 1.473 & -0.554 & -0.291 & -2.825 & $-3.492 *$ & $-5.897 * *$ \\
\hline & $(1.371)$ & $(1.601)$ & $(1.450)$ & $(1.582)$ & $(1.469)$ & $(1.788)$ \\
\hline \multirow[t]{2}{*}{2017} & $-4.565 * *$ & $-9.581 * * *$ & $-6.116^{* * *}$ & $-11.01 * * *$ & $-5.773 * * *$ & $-9.705 * * *$ \\
\hline & $(1.542)$ & $(2.190)$ & $(1.542)$ & $(1.954)$ & $(1.468)$ & $(2.292)$ \\
\hline \multirow[t]{2}{*}{$2008 \times$ Indigenous $>12 \%=1$} & -8.024 & -3.901 & $-18.32 * * *$ & $-15.99 *$ & $-16.16^{* *}$ & $-14.15^{*}$ \\
\hline & $(6.422)$ & $(6.858)$ & $(5.333)$ & $(6.205)$ & $(5.647)$ & $(6.091)$ \\
\hline \multirow[t]{2}{*}{$2009 \times$ Indigenous $>12 \%=1$} & $-11.22 *$ & -9.423 & $-14.93 * *$ & $-14.06^{* *}$ & $-12.57^{*}$ & $-12.08^{*}$ \\
\hline & $(5.393)$ & $(5.474)$ & $(4.824)$ & $(5.022)$ & (5.206) & $(5.126)$ \\
\hline \multirow[t]{2}{*}{$2010 \times$ Indigenous $>12 \%=1$} & -5.368 & -3.918 & $-17.96 * * *$ & $-17.17 * * *$ & -9.065 & -8.863 \\
\hline & $(4.547)$ & $(4.801)$ & $(4.907)$ & $(4.942)$ & $(5.411)$ & $(5.375)$ \\
\hline \multirow[t]{2}{*}{$2011 \times$ Indigenous $>12 \%=1$} & $-13.41^{*}$ & $-12.38^{*}$ & $-15.02 * * *$ & $-14.40 * * *$ & $-10.59^{*}$ & $-10.28^{*}$ \\
\hline & $(5.369)$ & $(5.366)$ & $(4.238)$ & $(4.263)$ & $(5.208)$ & $(5.130)$ \\
\hline \multirow[t]{2}{*}{$2012 \times$ Indigenous $>12 \%=1$} & -1.870 & -3.130 & $-13.75^{* *}$ & $-14.37 * *$ & -2.447 & -3.272 \\
\hline & $(3.809)$ & $(4.247)$ & $(4.283)$ & $(5.032)$ & $(4.221)$ & $(4.550)$ \\
\hline \multirow[t]{2}{*}{$2013 \times$ Indigenous $>12 \%=1$} & -2.026 & -1.754 & -8.974 & -8.755 & -4.593 & -4.388 \\
\hline & $(4.110)$ & $(4.132)$ & $(4.669)$ & $(4.654)$ & $(3.844)$ & $(3.785)$ \\
\hline \multirow[t]{2}{*}{$2015 \times$ Indigenous $>12 \%=1$} & -1.116 & -0.961 & 0.485 & -0.0386 & 1.431 & 1.186 \\
\hline & $(4.256)$ & $(4.206)$ & $(4.278)$ & $(4.384)$ & $(4.274)$ & $(4.233)$ \\
\hline \multirow[t]{2}{*}{$2016 \times$ Indigenous $>12 \%=1$} & $9.226 *$ & $8.513 *$ & 2.828 & 2.248 & $8.582 *$ & $8.745 *$ \\
\hline & $(3.862)$ & $(3.843)$ & $(3.806)$ & $(3.911)$ & $(3.525)$ & (3.573) \\
\hline \multirow[t]{2}{*}{$2017 \times$ Indigenous $>12 \%=1$} & 6.538 & 5.551 & -1.566 & -2.504 & 0.770 & 0.699 \\
\hline & $(4.567)$ & $(4.462)$ & $(3.504)$ & $(3.507)$ & $(4.525)$ & $(4.341)$ \\
\hline Canton fixed effects & YES & YES & YES & YES & YES & YES \\
\hline Year fixed effects & YES & YES & YES & YES & YES & YES \\
\hline Time-varying control variables & NO & YES & NO & YES & NO & YES \\
\hline
\end{tabular}


Test of joint significance for lead interactions ${ }^{£}$ :

$\begin{array}{ll}F(2,220) & 0.18\end{array}$

\subsection{4}

0.29

5.29

4.27

0.72

0.69

Prob. $>$ F

0.7505

0.0059

0.0151

Sources: Ecuador's National Registries of Live Births for 2008-2017; National Census and population projections.

Notes: Table presents event study models with three comparison groups.

Interaction term between year and Indigenous represent triple differences (DDD) in birth rates per 1000 women:

Delta 1 is for (teens - young adults)

Delta 2 is for (teens - late 20s)

Delta 3 is for (teens - early 30 s)

Robust standard errors in parentheses clustered at cantón level:

$* \mathrm{p}<0.05 * * \mathrm{p}<0.01 * * * \mathrm{p}<0.001$

Cantón is classified as high indigenous if percentage of women who self-identified as indigenous is above the national mean ( $>12 \%)$; low indigenous if that percentage is at or below the national mean $(\leq 12 \%)$.

Reference year is 2014 .

${ }^{£}$ Lead interactions defined as: $2012 \times$ Indigenous $>12 \%=1$ and $2013 \times$ Indigenous $>12 \%=1$.

Time-varying control variables include cantón-level means for: age, education, proportion Indigenous, married/in-union, institutional delivery, skill birth attendance, any prenatal control, and second-or-higher-order birth. 
Table 6

Effect of Abrupt Change in Sexual and Reproductive Health Policy on Adolescent Birth Rates in Ecuador 2011-2017: Logarithmic Triple Differences.

\begin{tabular}{|c|c|c|c|c|c|c|}
\hline & $\begin{array}{c}(1) \\
\text { Log } \\
\text { delta1 } \\
\text { (teen - } \\
\text { young } \\
\text { adult) } \\
\end{array}$ & $\begin{array}{c}\text { (2) } \\
\\
\text { Log } \\
\text { delta1 } \\
\text { (teen - young adult) }\end{array}$ & $\begin{array}{c}\text { Log } \\
\text { delta2 } \\
\text { (teen - } \\
\text { late20s) } \\
\end{array}$ & $\begin{array}{c}\text { Log } \\
\text { delta2 } \\
\text { (teen }- \text { late20s) } \\
\end{array}$ & $\begin{array}{c}\log \\
\text { delta3 } \\
\text { (teen - early30s) } \\
\end{array}$ & $\begin{array}{c}\log \\
\text { delta3 } \\
\text { (teen - early30s) }\end{array}$ \\
\hline Indigenous $>12 \%=1$ & $\begin{array}{l}-0.0489 \\
(0.0683)\end{array}$ & $\begin{array}{l}-0.0468 \\
(0.0649)\end{array}$ & $\begin{array}{l}-0.0540 \\
(0.0575)\end{array}$ & $\begin{array}{c}-0.0232 \\
(0.0515)\end{array}$ & $\begin{array}{l}-0.0102 \\
(0.0812)\end{array}$ & $\begin{array}{c}0.0117 \\
(0.0718)\end{array}$ \\
\hline Indigenous $>12 \%=1 \times$ Post $2014=1$ & $\begin{array}{l}0.0700^{* * *} \\
(0.0214)\end{array}$ & $\begin{array}{l}0.0636^{* *} \\
(0.0231)\end{array}$ & $\begin{array}{c}0.0956 * * * \\
(0.0281)\end{array}$ & $\begin{array}{l}0.0665^{*} \\
(0.0320)\end{array}$ & $\begin{array}{c}0.0867 * * * \\
(0.0258)\end{array}$ & $\begin{array}{c}0.0837^{* *} \\
(0.0291)\end{array}$ \\
\hline Canton fixed effects & YES & YES & YES & YES & YES & YES \\
\hline Year fixed effects & YES & YES & YES & YES & YES & YES \\
\hline Time-varying control variables & NO & YES & NO & YES & NO & YES \\
\hline Observations & 1547 & 1547 & 1547 & 1547 & 1547 & 1547 \\
\hline
\end{tabular}

Sources: Ecuador's National Registries of Live Births for 2008-2017; National Census and population projections.

Notes: Table presents fixed effects regression results.

Interaction term represents triple differences (DDD) in birth rates per 1000 women:

Log delta 1 is for (log teen birth rate - log young adult birth rate)

Log delta 2 is for (log teen birth rate - log late 20s birth rate)

Log delta 3 is for (log teen birth rate $-\log$ early 30 s birth rate)

Robust standard errors in parentheses clustered at canton level:

$* \mathrm{p}<0.05 * * \mathrm{p}<0.01 * * * \mathrm{p}<0.001$

Cantón is classified as high indigenous if percentage of women who self-identified as Indigenous is above the national mean ( $>12 \%)$; low indigenous if that percentage is at or below the national mean $(\leq 12 \%)$.

Post 2014 is a dummy variable $=1$ if year $>2014$. Because we have year fixed effects, we do not need Post2014 as a main effect.

Time-varying control variables include cantón-level means for: age, education, proportion Indigenous, married/in-union, institutional delivery, skill birth attendance, any prenatal control, and second-or-higher-order birth. 
Table 7

Effect of Abrupt Change in Sexual and Reproductive Health Policy on Adolescent Birth Rates in Ecuador 2011-2017: Triple Difference, Population Weighted Regression Results.
(1)

(2)

(3)

(4)

(5)

\begin{tabular}{|c|c|c|c|c|c|c|}
\hline & $\begin{array}{l}\text { Delta1 (teen - } \\
\text { young adult) }\end{array}$ & $\begin{array}{l}\text { Delta1 (teen } \\
\text { - young } \\
\text { adult) }\end{array}$ & $\begin{array}{l}\text { Delta2 } \\
\text { (teen - } \\
\text { late20s) }\end{array}$ & $\begin{array}{c}\text { Delta2 } \\
\text { (teen - } \\
\text { late20s) }\end{array}$ & $\begin{array}{l}\text { Delta3 (teen - } \\
\text { early30s) }\end{array}$ & $\begin{array}{l}\text { Delta3 (teen } \\
\text { - early30s) }\end{array}$ \\
\hline \multirow[t]{2}{*}{ Indigenous $>12 \%=1$} & -5.554 & $-5.675^{*}$ & -2.131 & -2.324 & $-5.067 * * *$ & $-4.942 * *$ \\
\hline & $(2.863)$ & $(2.792)$ & $(1.813)$ & $(1.617)$ & $(1.349)$ & $(1.559)$ \\
\hline \multirow[t]{2}{*}{ Indigenous $>12 \%=1 \times$ Post $2014=1$} & $8.110 * * *$ & $4.635^{* *}$ & $6.710 * *$ & 3.174 & $5.708 * *$ & $4.437^{*}$ \\
\hline & $(2.017)$ & $(\mathbf{1 . 6 0 3 )}$ & $(2.126)$ & $(\mathbf{1 . 8 8 2})$ & $(\mathbf{1 . 8 2 6})$ & $(1.739)$ \\
\hline Canton fixed effects & YES & YES & YES & YES & YES & YES \\
\hline Year fixed effects & YES & YES & YES & YES & YES & YES \\
\hline Time-varying control variables & NO & YES & NO & YES & NO & YES \\
\hline Observations & 1547 & 1547 & 1547 & 1547 & 1547 & 1547 \\
\hline
\end{tabular}

Sources: Ecuador's National Registries of Live Births for 2008-2017; National Census and population projections.

Notes: Table presents fixed effects regression results weighted by share of female teen (15-19) population according to 2010 Census.

Interaction term represents triple differences (DDD) in birth rates per 1000 women:

Delta 1 is for (teens - young adults)

Delta 2 is for (teens - late 20s)

Delta 3 is for (teens - early 30 s)

Robust standard errors in parentheses clustered at canton level:

$* \mathrm{p}<0.05 * * \mathrm{p}<0.01 * * * \mathrm{p}<0.001$

Cantón is classified as high indigenous if percentage of women who self-identified as Indigenous is above the national mean ( $>12 \%)$; low

indigenous if that percentage is at or below the national mean $(\leq 12 \%)$.

Post 2014 is a dummy variable $=1$ if year $>2014$. Because we have year fixed effects, we do not need Post2014 as a main effect.

Time-varying control variables include cantón-level means for: age, education, proportion Indigenous, married/in-union, institutional delivery, skill birth attendance, any prenatal control, and second-or-higher-order birth. 
Table 8

Effect of Abrupt Change in Sexual and Reproductive Health Policy on Adolescent Birth Rates in Ecuador 2011-2017: Triple Difference Regression Results, Using Post $>2015$.

(1)

\begin{tabular}{|c|c|c|c|c|c|c|}
\hline & $\begin{array}{l}\text { Delta1 (teen - } \\
\text { young adult) }\end{array}$ & $\begin{array}{c}\text { Delta1 (teen - } \\
\text { young adult) }\end{array}$ & $\begin{array}{c}\text { Delta2 } \\
\text { (teen - } \\
\text { late20s) }\end{array}$ & $\begin{array}{c}\text { Delta2 } \\
\text { (teen - } \\
\text { late20s) }\end{array}$ & $\begin{array}{l}\text { Delta3 (teen } \\
\text { - early30s) }\end{array}$ & $\begin{array}{l}\text { Delta3 (teen } \\
\text { - early30s) }\end{array}$ \\
\hline \multirow[t]{2}{*}{ Indigenous $>12 \%=1$} & -4.399 & -4.568 & -2.723 & -0.771 & 1.211 & 2.150 \\
\hline & (5.133) & $(5.131)$ & $(3.921)$ & (4.073) & $(4.627)$ & (4.443) \\
\hline Indigenous $>12 \%=1 \times$ Post $2015=1$ & $\begin{array}{c}11.47 * * * \\
(2.709)\end{array}$ & $\begin{array}{c}11.18 * * * \\
(2.818)\end{array}$ & $\begin{array}{l}7.800 * * \\
(2.518)\end{array}$ & $\begin{array}{l}6.151 * \\
(2.614)\end{array}$ & $\begin{array}{l}7.503 * * \\
(2.515)\end{array}$ & $\begin{array}{l}8.411 * * \\
(2.774)\end{array}$ \\
\hline Canton fixed effects & YES & YES & YES & YES & YES & YES \\
\hline Year fixed effects & YES & YES & YES & YES & YES & YES \\
\hline Time-varying control variables & NO & YES & NO & YES & NO & YES \\
\hline Observations & 1547 & 1547 & 1547 & 1547 & 1547 & 1547 \\
\hline
\end{tabular}

Sources: Ecuador's National Registries of Live Births for 2008-2017; National Census and population projections.

Notes: Table presents fixed effects regression results.

Interaction term represents triple differences (DDD) in birth rates per 1000 women:

Delta 1 is for (teens - young adults)

Delta 2 is for (teens - late 20s)

Delta 3 is for (teens - early 30 s)

Robust standard errors in parentheses clustered at canton level:

$* \mathrm{p}<0.05 * * \mathrm{p}<0.01 * * * \mathrm{p}<0.001$

Cantón is classified as high indigenous if percentage of women who self-identified as Indigenous is above the national mean ( $>12 \%)$; low indigenous if that percentage is at or below the national mean $(\leq 12 \%)$.

Post 2015 is a dummy variable $=1$ if year $>2015$. Because we have year fixed effects, we do not need Post2015 as a main effect.

Time-varying control variables include cantón-level means for: age, education, proportion Indigenous, married/in-union, institutional delivery, skill birth attendance, any prenatal control, and second-or-higher-order birth. 
Table 9

Triple Difference Effect of Abrupt Change in SRH Policy on Teen Birth Rates using Pre-ENIPLA only as PreIntervention Period.

\begin{tabular}{lcccccc} 
& $\begin{array}{c}\text { Delta1 (teen } \\
\text { young adult) }\end{array}$ & $\begin{array}{c}\text { - young } \\
\text { adult) }\end{array}$ & $\begin{array}{c}\text { Delta2 (teen } \\
- \text { late20s) }\end{array}$ & $\begin{array}{c}\text { Delta2 (teen } \\
- \text { late20s) }\end{array}$ & $\begin{array}{c}\text { Delta3 (teen } \\
\text { - early30s) }\end{array}$ & $\begin{array}{c}\text { Delta3 (teen } \\
\text { - early30s) }\end{array}$ \\
\hline Indigenous $>12 \%=1$ & -1.035 & -0.998 & 0.510 & 1.900 & 2.253 & 3.873 \\
& $(5.958)$ & $(5.657)$ & $(5.687)$ & $(5.686)$ & $(5.454)$ & $(5.530)$ \\
Indigenous $>\mathbf{1 2 \%}=\mathbf{1} \times$ Post $\mathbf{2 0 1 4}=\mathbf{1}$ & $\mathbf{1 3 . 3 4 * *}$ & $\mathbf{8 . 6 7 5 *}$ & $\mathbf{1 8 . 0 1 * * *}$ & $\mathbf{1 4 . 9 7 * *}$ & $\mathbf{1 6 . 0 4 * * *}$ & $\mathbf{1 2 . 8 8 * *}$ \\
& $\mathbf{( 4 . 2 6 0 )}$ & $\mathbf{( 4 . 2 7 5 )}$ & $\mathbf{( 4 . 6 1 0 )}$ & $\mathbf{( 4 . 5 0 6 )}$ & $\mathbf{( 3 . 8 4 4 )}$ & $\mathbf{( 3 . 9 2 0 )}$ \\
Canton fixed effects & YES & YES & YES & YES & YES & YES \\
Year fixed effects & YES & YES & YES & YES & YES & YES \\
Time-varying control variables & NO & YES & NO & YES & NO & YES \\
Observations & 1326 & 1326 & 1326 & 1326 & 1326 & 1326 \\
\hline
\end{tabular}

Sources: Ecuador's National Registries of Live Births for 2008-2017; National Census and population projections.

Notes: Table presents fixed effects regression results for 2008-2017 with the ENIPLA period (2011-2014) excluded.

Interaction term represents triple differences (DDD) in birth rates per 1000 women:

Delta 1 is for (teens - young adults)

Delta 2 is for (teens - late 20s)

Delta 3 is for (teens - early 30 s)

Robust standard errors in parentheses clustered at canton level:

$* \mathrm{p}<0.05 * * \mathrm{p}<0.01 * * * \mathrm{p}<0.001$

Cantón is classified as high indigenous if percentage of women who self-identified as Indigenous is above the national mean ( $>12 \%)$; low indigenous if that percentage is at or below the national mean $(\leq 12 \%)$

Post 2014 is a dummy variable $=1$ if year $>2014$. Because we have year fixed effects, we do not need Post2014 as a main effect.

Time-varying control variables include cantón-level means for: age, education, proportion Indigenous, married/in-union, institutional delivery, skill birth attendance, any prenatal control, and second-or-higher-order birth. 
Table 10

Secondary Results: Triple Difference Effect of ENIPLA on Teen Birth Rates: 2008-2014.

(1)

Delta1 Delta1

(teen - (teen -

young young

adult) adult)

Indigenous $>12 \%=1$

$0.382 \quad 0.774$

$(4.098) \quad(3.893)$

Indigenous $>12 \%=1 \times$ Post $2010=1$

3.775

2.858

Canton fixed effects

(3.312) (3.393)

Year fixed effects

YES YES

Time-varying control variables

YES YES

Observations

NO YES

$1547 \quad 1547$

Sources: Ecuador's National Registries of Live Births for 2008-2017; National Census and population projections.

Notes: Table presents fixed effects regression results.

Interaction term represents triple differences (DDD) in birth rates per 1000 women:

Delta 1 is for (teens - young adults)

Robust standard errors in parentheses clustered at canton level:

$* \mathrm{p}<0.05 * * \mathrm{p}<0.01 * * * \mathrm{p}<0.001$

Cantón is classified as high indigenous if percentage of women who self-identified as Indigenous is above the national mean ( $>12 \%)$; low indigenous if that percentage is at or below the national mean $(\leq 12 \%)$.

Post 2010 is a dummy variable $=1$ if year $>2010$. Because we have year fixed effects, we do not need Post2010 as a main effect.

Time-varying control variables include cantón-level means for: age, education, proportion Indigenous, married/in-union, institutional delivery, skill birth attendance, any prenatal control, and second-or-higher-order birth. 


\section{References}

Anderson, I., Robson, B., Connolly, M., Al-yaman, F., Bjertness, E., King, A., Tynan, M., Madden, R., 2016. Indigenous and tribal peoples ' health ( The Lancet - Lowitja Institute Global Collaboration): a population study. Lancet 388, 131-157. doi:10.1016/S0140-6736(16)00345-7

Azevedo, J.P., Favara, M., Haddock, S.E., Lopez-Calva, L.F., Müller, M., Perova, E., 2012. Teenage Pregnancy and Opportunities in Latin America and the Caribbean, The World Bank. Washington, DC.

Barro, R.J., 1973. The Control of Politicians: An Economic Model. Public Choice 14, 19-42.

Berthelon, M.E., Kruger, D.I., 2011. Risky behavior among youth: Incapacitation effects of school on adolescent motherhood and crime in Chile. J. Public Econ. 95, 41-53. doi:10.1016/j.jpubeco.2010.09.004

Bertrand, M., Duflo, E., Mullainathan, S., 2004. How Much Should We Trust Differences-In-Differences Estimates? Q. J. Econ. 119, 249-275. doi:https://doi.org/10.1162/003355304772839588

Branson, N., Byker, T., 2018. Causes and Consequences of Teen Childbearing: Evidence from a Reproductive Health Intervention in South Africa. J. Health Econ. 57, 221-35. doi:10.1016/j.jhealeco.2017.11.006

Bucheli, A., Masabanda, M., Illapa, M., Jumbo, J., Ortega, J., 2014. Instructivo de Implementación del Reglamento para regular el acceso a métodos anticonceptivos - Acuerdo Ministerial 2490 [Implementation Instructions for Regulation for access to contraceptive methods - Ministerial Agreement 2490]. Ministerio de Salud Pública (MSP) [Ministry of Public Health], Quito, Ecuador.

Burneo Salazar, C., Córdova Páez, A., Gutiérrez, M.J., Ordoñez, A., 2015. Embarazo Adolescente en el Marco De La Estrategia Nacional Intersectorial De Planificación Familiar (ENIPLA) 2014 Y El Plan Nacional De Fortalecimiento de la Familia 2015 [WWW Document]. URL http://saludyderechos.fundaciondonum.org/wp-content/uploads/2015/06/SEXUALIDADADOLESCENTE-PDF.pdf (accessed 6.21.19).

Buvinic, M., 1998. The costs of adolescent childbearing: evidence from Chile, Barbados, Guatemala, and Mexico. Stud. Fam. Plann. 29, 201-9.

Carr, J.B., Packham, A., 2017. The Effects of State-Mandated Abstinence-Based Sex Education on Teen Health Outcomes. Health Econ. 26, 403-420. doi:10.1002/hec.3315

Carrera, S., Yunga, J., 2016. Nota técnica: Registro de Estadísticas Vitales-Nacidos vivos y Defunciones 2015 [WWW Document]. URL http://www.ecuadorencifras.gob.ec/documentos/webinec/Poblacion_y_Demografia/Nacimientos_Defunciones/2015/Nota_tecnica_Registro_de_Estadisticas_Vi tales_2015.pdf(accessed 6.18.19).

Correa, R., 2015. Enlace Ciudadano 413 desde Carcelén Alto [WWW Document]. El Comer. URL https://www.elcomercio.com/actualidad/enlace-ciudadano-413-carcelen-alto.html (accessed 6.18.19).

Craig, P., Katikireddi, S.V., Leyland, A., Popham, F., 2017. Natural Experiments: An Overview of Methods, Approaches, and Contributions to Public Health Intervention Research. Annu. Rev. Public Health 38, 3956. doi:10.1146/annurev-publhealth-031816-044327

Deb, P., Norton, E.C., Manning, W.G., 2017. Health econometrics using Stata. Stata Press, College Station, TX.

Diaz, C.J., Fiel, J.E., 2016. The Effect(s) of Teen Pregnancy: Reconciling Theory, Methods, and Findings. Demography 53, 85-116. doi:10.1007/s13524-015-0446-6

Donohue, J.J., Grogger, J., Levitt, S.D., 2009. The impact of legalized abortion on teen childbearing. Am. Law Econ. Rev. 11, 24-46. doi:10.1093/aler/ahp006 
Edwards, S., 2019. On Latin American Populism, and Its Echoes around the World. J. Econ. Perspect. 33, 7699.

El Universo, R., 2015a. En Enipla hubo una ' agenda abortista y gay', dice Rafael Correa [ENIPLA had abortionist and gay agenda, says Rafael Correa] [WWW Document]. El Universo. URL https:/www.eluniverso.com/noticias/2015/04/02/nota/4728121/enipla-hubo-agenda-abortista-gay-dicecorrea

El Universo, R., 2015b. Mónica Hernández: ‘ Daremos mucho énfasis a la abstinencia ’ ["We will very much emphasize abstinence"] [WWW Document]. El Universo. URL https:/www.eluniverso.com/noticias/2015/03/08/nota/4630786/daremos-mucho-enfasis-abstinencia (accessed 4.23.20).

El Universo, R., 2015c. Salud sexual en Ecuador sujeta a cambios en Ecuador [Sexual health subject to changes in Ecuador] [WWW Document]. El Universo. URL https:/www.eluniverso.com/noticias/2015/03/08/nota/4630796/salud-sexual-sujeta-cambios (accessed 4.23.20).

Ellner, S., 2012. The distinguishing features of Latin America's new left in power: The Chávez, Morales, and Correa governments. Lat. Am. Perspect. 39, 96-114. doi:10.1177/0094582X11425333

Estrella, S., 2015. Para el Presidente, con el Enipla se distribuía condones como chicles [For the President, ENIPLA distributed condoms as if they were chewing gum] [WWW Document]. El Comer. URL http://www.elcomercio.com/actualidad/rafaelcorrea-enipla-distribuia-condones-sexualidad.html (accessed 1.11.19).

Freire, W., Ramírez-Luzuriaga, M., Belmont, P., Mendieta, M., Silva-Jaramillo, M., Romero, N., Sáenz, K., Piñeiros, P., Gómez, L., Monge, R., 2015. Tomo II: Encuesta Nacional de Salud y Nutrición de la población ecuatoriana. ENSANUT-ECU 2012. [National Health and Nutrition Survey ENSANUT-EC 2012 Vol.2]. Ministerio de Salud Pública (MSP)/Instituto Nacional de Estadísticas y Censos (INEC), Quito, Ecuador.

Galárraga, O., Harris, J., 2019. Effect of an Abrupt Change in Sexual and Reproductive Health Policy on Adolescent Birth Rates in Ecuador, 2008-2017. NBER Work. Pap. 28. doi:10.3386/w26044

Goicolea, I., Coe, A.B., San Sebastián, M., Hurtig, A.K., 2017. Developing and sustaining adolescent-friendly health services: A multiple case study from Ecuador and Peru. Glob. Public Health 12, 1004-1017. doi:10.1080/17441692.2015.1123752

Goicolea, I., Sebastian, M.S., 2010. Unintended pregnancy in the amazon basin of Ecuador: a multilevel analysis. Int. J. Equity Health 9, 14. doi:10.1186/1475-9276-9-14

Heissel, J.A., 2017. Teenage motherhood and sibling outcomes. Am. Econ. Rev. 107, 633-637. doi:10.1257/aer.p20171130

Kearney, M.S., Levine, P.B., 2015. Investigating recent trends in the U.S. teen birth rate. J. Health Econ. 41, 15-29. doi:10.1016/j.jhealeco.2015.01.003

Kearney, M.S., Levine, P.B., 2012. Why is the Teen Birth Rate in the United States So High and Why Does It Matter? J. Econ. Perspect. 26, 141-166. doi:10.1257/jep.26.2.141

Marteleto, L.J., Villanueva, A., 2018. The Educational Consequences of Adolescent Childbearing and Union Formation in Brazil. Stud. Fam. Plann. 49, 183-211. doi:10.1111/sifp.12071

Ministerio Coordinador de Desarrollo Social, 2011. Estrategia Intersectorial de Prevención del Embarazo Adolescente y Planificación Familiar [WWW Document]. Estrateg. Intersectorial Prevención del 
Embarazo Adolesc. y Planif. Fam. URL http:/www.todaunavida.gob.ec/wpcontent/uploads/downloads/2015/04/Proyecto_enipla.pdf

MSP, 2018. Panel 2: retos pendientes para garantizar el acceso a la salud sexual y reproductiva, y para cerrar las brechas de género [Current challenges to guarantee access to sexual and reproductive health and close gender gaps] [WWW Document]. Conf. Reg. sobre Población y Desarro. URL https://crpd.cepal.org/3/sites/crpd3/files/presentations/panel_2_ecuador.pdf (accessed 6.4.19).

MSP, 2012. Manual del Modelo de Atención Integral de Salud (MAIS) [WWW Document]. URL http://instituciones.msp.gob.ec/somossalud/images/documentos/guia/Manual_MAIS-MSP12.12.12.pdf

Nicolalde-Escobar, N.N., 2016. Influencia del discurso moralista en la toma de decisiones dentro del poder ejecutivo ( 2014- 2015 ): Proyecto “Plan Familia" e implicaciones en los derechos de la mujer [WWW Document]. [Moralistic discourse in decision-making within executive branch (2014-2015): Plan Familia and implications for women's rights]. URL http://repositorio.usfq.edu.ec/bitstream/23000/5783/1/124888.pdf

Official Register, 2014. Derecho Ecuador - Registro Oficial [WWW Document]. Off. Pres. URL https://derechoecuador.com/registro-oficial/2014/12/registro-oficial-no-395---viernes-12-de-diciembre-2014-suplemento (accessed 6.18.19).

Packham, A., 2017. Family planning funding cuts and teen childbearing. J. Health Econ. 55, 168-185. doi:10.1016/j.jhealeco.2017.07.002

Paz-y-Miño, C., 2014. Habla serio, sexualidad sin misterios [All joking aside, sexuality without mystery] [WWW Document]. El Telégrafo. URL http://tinyurl.com/yxgo8k8t (accessed 4.27.20).

Posner, P.W., 2016. Laboring Under Chávez: Populism for the Twenty-first Century. Lat. Am. Polit. Soc. 58, 26-50. doi:10.1111/j.1548-2456.2016.00317.x

Presidencia de la República del Ecuador, 2015. Proyecto Plan Nacional de Fortalecimiento de la Familia [WWW Document]. URL https:/www.presidencia.gob.ec/wpcontent/uploads/downloads/2015/09/k_proyecto_plan_familia_2015.pdf(accessed 6.30.19).

Reuters, 2019. Ecuador abortion: National Assembly rejects easing law in rape cases [WWW Document]. BBC News. URL https://www.bbc.com/news/world-latin-america-49739495 (accessed 5.7.20).

Ridder, G., Moffitt, R., 2007. Chapter 75 The Econometrics of Data Combination. Handb. Econom. 6, 54695547. doi:10.1016/S1573-4412(07)06075-8

Rivas, J., 2016. Private agenda and re-election incentives. Soc. Choice Welfare 46, 899-915. doi:10.1007/s00355-015-0941-0

Salcedo, A., Silva, V., Holguín, W., Hidalgo, S., Uquillas, O., Torres, J., Puga, E., Vásquez, S., Cárdenas, N., Santillán, V., Lucero, S., 2014. Distribución espacial referencial de los establecimientos prestadores de servicios públicos [Geographic distribution for public healthcare establishments], Guía técnica. Secretaría Nacional de Planificación y Desarrollo [National Secretary of Planning and Development], Quito, Ecuador.

Strupat, C., 2017. Do Targeted Reproductive Health Services Matter? - The Impact of a Midwife Program in Indonesia. Heal. Econ. (United Kingdom) 26, 1667-1681. doi:10.1002/hec.3465

The Economist, 2019. Latin America is losing its battle against teen pregnancy: Why rates of early motherhood are so high [WWW Document]. Econ. URL https://www.economist.com/the-americas/2019/02/16/latinamerica-is-losing-its-battle-against-teen-pregnancy (accessed 12.11.19). 
Trenholm, C., Devaney, B., Fortson, K., Clark, M., Bridgespan, L.Q., Wheeler, J., 2008. Impacts of Abstinence Education on Teen Sexual Activity, Risk of Pregnancy, and Risk of Sexually Transmitted Diseases. J. Policy Anal. Manag. 27, 255-276. doi:10.1002/pam.20324

Underhill, K., Montgomery, P., Operario, D., 2007. Sexual abstinence only programmes to prevent HIV infection in high income countries: systematic review. BMJ 335, 248. doi:10.1136/bmj.39245.446586.BE

UNFPA, 2013. Motherhood in Childhood: Facing the Challenge of Adolescent Pregnancy. United Nations Population Fund (UNFPA), New York.

Waters, W.F., Ehlers, J., Ortega, F., Kuhlmann, A.S., 2018. Physically Demanding Labor and Health Among Indigenous Women in the Ecuadorian Highlands. J. Community Health 43, 220-226. doi:10.1007/s10900017-0407-7

Wing, C., Simon, K., Bello-Gomez, R.A., 2018. Designing Difference in Difference Studies: Best Practices for Public Health Policy Research. Annu. Rev. Public Health 39, 453-69. doi:10.1146/annurev-publhealth

Wooldridge, J.M., 2010. Econometric Analysis of Cross Section and Panel Data (Second Edition). MIT Press, Cambridge, MA. 


\section{APPENDIX}

\section{Appendix Table A1}

Methods of contraception used by sexually active teen (15-19 yrs.) and young adult women (20-24 yrs.).

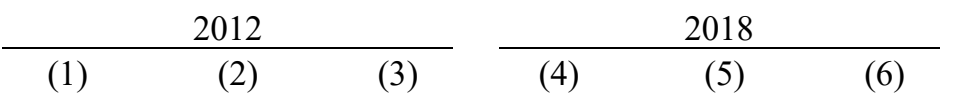

Teens Young adult diff. Teens Young adult diff. $\quad$ Diff. in diff.

\begin{tabular}{lccccccc} 
A. Methods ever used (conditional on ever having sex) & & & & & \\
Any method & 77.5 & 88.6 & -11.0 & 82.2 & 92.3 & -10.1 & 0.9 \\
Condom & 50.5 & 56.8 & -6.3 & 48.3 & 56.8 & -8.5 & -2.2 \\
Pill & 33.2 & 47.1 & -13.9 & 29.0 & 43.1 & -14.1 & -0.2 \\
Injectable & 24.1 & 38.8 & -14.7 & 28.5 & 45.2 & -16.7 & -2.1 \\
Implant & 12.8 & 13.1 & -0.3 & 20.5 & 29.5 & -9.1 & -8.8 \\
Emergency contraception & 7.7 & 11.7 & -4.0 & 17.8 & 22.9 & -5.1 & -1.1 \\
Withdrawal & 23.3 & 27.4 & -4.1 & 12.7 & 15.8 & -3.1 & 1.0 \\
Rhythm & 11.8 & 18.4 & -6.6 & 6.7 & 13.5 & -6.9 & -0.3 \\
Female condom & 3.9 & 4.7 & -0.8 & 3.9 & 6.1 & -2.2 & -1.4 \\
Intrauterine device & 5.1 & 9.5 & -4.4 & 1.8 & 4.9 & -3.1 & 1.3 \\
Lactational amenorrhea & 2.3 & 3.8 & -1.6 & 1.3 & 2.5 & -1.2 & 0.4 \\
Other & 4.0 & 3.9 & 0.1 & 0.02 & 0.12 & -0.1 & -0.2 \\
B. Methods currently used now & (conditional on having sex in the past 30 days) & & & \\
Any method & 46.9 & 59.6 & -12.7 & 51.9 & 67.0 & -15.2 & -2.5 \\
Condom & 9.8 & 10.1 & -0.3 & 11.8 & 12.7 & -0.9 & -0.6 \\
Pill & 10.2 & 12.3 & -2.2 & 8.8 & 12.3 & -3.5 & -1.4 \\
Injectable & 10.4 & 14.2 & -3.8 & 13.4 & 20.4 & -7.0 & -3.3 \\
Implant & 10.1 & 11.1 & -1.0 & 16.2 & 17.4 & -1.2 & -0.1 \\
Emergency contraception & 1.4 & 0.7 & 0.7 & 0.8 & 1.1 & -0.3 & -1.1 \\
Withdrawal & 7.1 & 6.5 & 0.6 & 3.2 & 4.2 & -1.0 & -1.6 \\
Rhythm & 3.2 & 5.0 & -1.8 & 2.2 & 4.3 & -2.1 & -0.3 \\
Female condom & 0.03 & 0.2 & -0.2 & 0.51 & 0.45 & 0.1 & 0.2 \\
Intrauterine device & 3.7 & 3.9 & -0.2 & 0.6 & 1.9 & -1.3 & -1.0 \\
Lactational amenorrhea & 0.8 & 1.3 & -0.6 & 0.5 & 0.5 & 0.0 & 0.6 \\
Other & 0.3 & 0.2 & 0.1 & 0.02 & 0.07 & -0.1 & -0.1 \\
\hline
\end{tabular}

Sources: Ecuador National Health and Nutrition Surveys, ENSANUT 2012 and 2018.

Notes: Table shows percentages from nationally representative sample of sexually active female teens (15-19 years) and young adult women (20-24 years).

The analysis pools the last two nationally representative health surveys (ENSANUT 2012 and 2018) as repeated cross-sections and estimates a differences-in-differences (DD) of contraception use (ever and now). The first differences are presented in columns 3 and 6 for 2012 and 2018 respectively; and the DD is in column 7, which shows the results of the differences in 2018 minus the differences in 2012 (i.e., column 6 - column 3 ). For example, the table shows that over three quarters of teens (78\% in 2012 and 82\% in 2018, columns 1 and 4) report having used some contraception method at some point; in fact, half of teenage women (50\% in 2012 and $48 \%$ in 2018$)$ report having used (male) condoms. Hormonal contraception (pill use) is the next most common form, with a third (33\% in 2012 and 29\% in 2018) of teen women reporting having used the pill. While injectable, implant, and emergency contraception use seems to have increased, the use of withdrawal and rhythm methods seems to have decreased among teens. Data for young adult women (columns 2 and 5) are used for comparison. A large majority of young adult women (89\% in 2012 and 92\% in 2018) report having used some method; though still only slightly more than half (57\% in both 2012 and 2018) report (male) condom use. Pill use is also the next most common form, with almost half (47\% in 2012) of young adults reporting use; yet lowering (to $43 \%$ in 2018). 


\section{Appendix Table A2}

Effect of Abrupt Change in Sexual and Reproductive Health Policy on Adolescent Birth Rates in Ecuador 2011-2017: Triple Difference Population Average Model with Autoregressive (AR3) Serial Correlation.

(1)

(2)

(3)
(4)

Delta1

(teen young adult)

Indigenous $>12 \%=1$

Indigenous $>12 \%=1 \times$ Post 2014=1

Canton fixed effects

Year fixed effects

Time-varying control variables

Observations

$-8.601 * * *$

$6.716 * *$

(2.092)

YES

YES

NO
Delta2

Delta1 (teen - $\quad$ (teen young adult) late20s)

Delta2 (teen -

Delta3 (teen late20s) early $30 \mathrm{~s})$

(5)

\begin{tabular}{cccc}
-4.746 & 2.099 & -5.651 & 2.172 \\
$(2.644)$ & $(3.651)$ & $(3.005)$ & $(3.413)$ \\
$\mathbf{6 . 7 3 3}^{* *}$ & $\mathbf{6 . 8 9 3}^{*}$ & $\mathbf{5 . 4 1 2} * *$ & $\mathbf{7 . 5 8 0 * * *}$ \\
$\mathbf{( 2 . 6 1 1 )}$ & $\mathbf{( 2 . 7 4 9 )}$ & $\mathbf{( 2 . 0 9 6 )}$ & $\mathbf{( 2 . 2 5 3 )}$ \\
YES & YES & YES & YES \\
YES & YES & YES & YES \\
NO & YES & NO & YES \\
1547 & 1547 & 1547 & 1547 \\
\hline
\end{tabular}

Sources: Ecuador's National Registries of Live Births for 2008-2017; National Census and population projections.

Notes: Table presents population average models correcting for three-period serial, autocorrelation (AR3).

Interaction term represents triple differences (DDD) in birth rates per 1000 women:

Delta 1 is for (teens - young adults)

Delta 2 is for (teens - late 20s)

Delta 3 is for (teens - early 30s)

Robust standard errors in parentheses clustered at canton level:

$* \mathrm{p}<0.05 * * \mathrm{p}<0.01 * * * \mathrm{p}<0.001$

Cantón is classified as high indigenous if percentage of women who self-identified as Indigenous is above the mean (>12\%); low indigenous if that percentage is at or below the mean $(\leq 12 \%)$.

Post 2014 is a dummy variable $=1$ if year $>2014$. Because we have year fixed effects, we do not need Post2014 as a main effect.

Time-varying control variables include cantón-level means for: age, education, proportion Indigenous, married/in-union, institutional delivery, skill birth attendance, any prenatal control, and second-or-higher-order birth. 


\section{Appendix Table A3}

Effect of Abrupt Change in Sexual and Reproductive Health Policy on Adolescent Birth Rates in Ecuador 2011-2017, Triple Difference Regression Results Using ENIPLA (2011-2014) as Pre-Intervention Period: Alternative Specification with Unrestricted Coefficient for Comparison Groups.

\begin{tabular}{|c|c|c|c|c|c|c|}
\hline & (1) & (2) & (3) & (4) & $(5)$ & (6) \\
\hline & $\begin{array}{l}\text { Teen } \\
\text { birthrate }\end{array}$ & $\begin{array}{l}\text { Teen } \\
\text { birthrate }\end{array}$ & $\begin{array}{l}\text { Teen } \\
\text { birthrate }\end{array}$ & $\begin{array}{l}\text { Teen } \\
\text { birthrate }\end{array}$ & $\begin{array}{l}\text { Teen } \\
\text { birthrate }\end{array}$ & $\begin{array}{l}\text { Teen } \\
\text { birthrate }\end{array}$ \\
\hline Young adult birthrate & $\begin{array}{l}0.283 * * * \\
(0.0208)\end{array}$ & $\begin{array}{l}0.282 * * * \\
(0.0209)\end{array}$ & & & & \\
\hline Adult late20s birthrate & & & $\begin{array}{l}0.268 * * * \\
(0.0226)\end{array}$ & $\begin{array}{l}0.268 * * * \\
(0.0230)\end{array}$ & & \\
\hline Adult early30s birthrate & & & & & $\begin{array}{l}0.238 * * * \\
(0.0273)\end{array}$ & $\begin{array}{l}0.237 * * * \\
(0.0274)\end{array}$ \\
\hline Indigenous $>12 \%=1$ & $\begin{array}{l}0.0933 \\
(3.242)\end{array}$ & $\begin{array}{l}-0.584 \\
(3.284)\end{array}$ & $\begin{array}{l}0.437 \\
(3.291)\end{array}$ & $\begin{array}{l}0.385 \\
(3.335)\end{array}$ & $\begin{array}{l}1.696 \\
(3.364)\end{array}$ & $\begin{array}{l}1.213 \\
(3.406)\end{array}$ \\
\hline Indigenous $>12 \%=1 \times$ Post $2014=1$ & $\begin{array}{l}4.484 * * \\
(1.505)\end{array}$ & $\begin{array}{l}5.284 * * * \\
(1.579)\end{array}$ & $\begin{array}{l}4.538 * * \\
(1.529)\end{array}$ & $\begin{array}{l}5.050 * * \\
(1.604)\end{array}$ & $\begin{array}{l}3.848 * \\
(1.562)\end{array}$ & $\begin{array}{l}5.082 * * \\
(1.640)\end{array}$ \\
\hline Constant & $\begin{array}{l}50.24 * * * \\
(2.506)\end{array}$ & $\begin{array}{l}36.65 \\
(34.41)\end{array}$ & $\begin{array}{l}55.73 * * * \\
(2.395)\end{array}$ & $\begin{array}{l}42.30 \\
(34.95)\end{array}$ & $\begin{array}{l}62.51 * * * \\
(2.378)\end{array}$ & $\begin{array}{l}29.24 \\
(35.83)\end{array}$ \\
\hline Canton fixed effects & YES & YES & YES & YES & YES & YES \\
\hline Year fixed effects & YES & YES & YES & YES & YES & YES \\
\hline Time-varying control variables & NO & YES & NO & YES & NO & YES \\
\hline Observations & 1547 & 1547 & 1547 & 1547 & 1547 & 1547 \\
\hline
\end{tabular}

Sources: Ecuador's National Registries of Live Births for 2008-2017; National Census and population projections.

Notes: Appendix Table A3 shows results of alternative specification of equation 1 where the dependent variable is the teen birthrate $(T R)$ and the comparison group birthrate $(C R)$ is included as a control variable as follows:

$T R_{j t}=\beta^{l} C R_{j t}+\beta^{2} I N D_{j}+\beta^{3} I N D_{j} \times$ Post $_{t}+\boldsymbol{\beta}_{t}{ }^{4}+\boldsymbol{\beta}_{j}{ }^{5}+\boldsymbol{\beta}^{6} Z_{j}+v_{j t}$

Table presents canton and year fixed effects with unrestricted model using each comparison group.

Columns (1) and (2) use young adults as comparison group.

Columns (3) and (4) use women in their late20s as comparison group.

Columns (5) and (6) use women in their early30s as comparison group.

Robust standard errors in parentheses clustered at canton level:

$* \mathrm{p}<0.05 * * \mathrm{p}<0.01 * * * \mathrm{p}<0.001$

Cantón is classified as high indigenous if percentage of women who self-identified as indigenous is above the national mean (>12\%); low indigenous if that percentage is at or below the national mean $(\leq 12 \%)$.

Post 2014 is a dummy variable $=1$ if year $>2014$. Because we have year fixed effects, we do not need Post2014 as a main effect.

Time-varying control variables include cantón-level means for: age, education, proportion Indigenous, married/in-union, institutional delivery, skill birth attendance, any prenatal control, and second-or-higher-order birth. 


\section{Appendix Table A4}

Effect of Abrupt Change in Sexual and Reproductive Health Policy on Adolescent Birth Rates in Ecuador 2011-2017, Triple Difference Regression Results Using ENIPLA (2011-2014) as Pre-Intervention Period: Time-Invariant Definition for Highly Indigenous Cantons.

\begin{tabular}{|c|c|c|c|c|c|c|}
\hline & $\begin{array}{l}\text { Delta1 (teen - } \\
\text { young adult) }\end{array}$ & $\begin{array}{l}\text { Delta1 (teen - } \\
\text { young adult) }\end{array}$ & $\begin{array}{l}\text { Delta2 (teen } \\
\text { - late20s) }\end{array}$ & $\begin{array}{l}\text { Delta2 (teen } \\
\text { - late20s) }\end{array}$ & $\begin{array}{l}\text { Delta3 (teen - } \\
\text { early30s) }\end{array}$ & $\begin{array}{l}\text { Delta3 (teen } \\
\text { - early30s) }\end{array}$ \\
\hline ind $2=1 \times$ Post $2014=1$ & $\begin{array}{c}9.034 * * * \\
(2.261)\end{array}$ & $\begin{array}{c}8.547 * * * \\
(2.272)\end{array}$ & $\begin{array}{c}9.702 * * * \\
(2.767)\end{array}$ & $\begin{array}{c}8.078 * * \\
(3.018)\end{array}$ & $\begin{array}{c}7.370 * * * \\
(2.089)\end{array}$ & $\begin{array}{c}8.347 * * * \\
(2.356)\end{array}$ \\
\hline Canton fixed effects & YES & YES & YES & YES & YES & YES \\
\hline Year fixed effects & YES & YES & YES & YES & YES & YES \\
\hline Time-varying control variables & NO & YES & NO & YES & NO & YES \\
\hline Observations & 1547 & 1547 & 1547 & 1547 & 1547 & 1547 \\
\hline
\end{tabular}

Sources: Ecuador's National Registries of Live Births for 2008-2017; National Census and population projections.

Notes: Table presents fixed effects regression results using a time-invariant definition for highly indigenous cantons; thus the ind2 variable drops out. Interaction term represents triple differences (DDD) in birth rates per 1000 women:

Delta 1 is for (teens - young adults)

Delta 2 is for (teens - late 20s)

Delta 3 is for (teens - early 30 s)

Robust standard errors in parentheses clustered at canton level:

$* \mathrm{p}<0.05 * * \mathrm{p}<0.01 * * * \mathrm{p}<0.001$

Under the ind2 time-invariant definition, a cantón is classified as high indigenous if the percentage of women who self-identified as indigenous across all years $(2008-2017)$ is above the national mean $(>12 \%)$; low indigenous if that percentage is at or below the national mean $(\leq 12 \%)$. Because ind2 is time invariant, it drops out as a main effect.

Post 2014 is a dummy variable $=1$ if year $>2014$. Because we have year fixed effects, we do not need Post2014 as a main effect.

Time-varying control variables include cantón-level means for: age, education, proportion Indigenous, married/in-union, institutional delivery, skill birth attendance, any prenatal control, and second-or-higher-order birth. 


\section{Appendix Table A5}

Effect of Abrupt Change in Sexual and Reproductive Health Policy on Adolescent Birth Rates in Ecuador 2011-2017, Triple Difference Regression Results Using ENIPLA (2011-2014) as Pre-Intervention Period: Time-Invariant Quintilebased Definition for Highly Indigenous Cantons.

(3)

(4)

(5)

\begin{tabular}{lcccccc} 
& $\begin{array}{c}\text { Delta1 (teen - } \\
\text { young adult) }\end{array}$ & $\begin{array}{c}\text { Delta1 (teen - } \\
\text { young adult) }\end{array}$ & $\begin{array}{c}\text { Delta2 (teen - } \\
\text { late20s) }\end{array}$ & $\begin{array}{c}\text { Delta2 (teen - } \\
\text { late20s) }\end{array}$ & $\begin{array}{c}\text { Delta3 (teen - } \\
\text { early30s) }\end{array}$ & $\begin{array}{c}\text { Delta3 (teen - } \\
\text { early30s) }\end{array}$ \\
\hline ind3=1 $\times$ Post 2014=1 & $\mathbf{7 . 1 8 1 * * *}$ & $\mathbf{6 . 6 1 6} * * *$ & $\mathbf{8 . 7 4 0} * * *$ & $\mathbf{7 . 4 5 2}^{* *}$ & $\mathbf{5 . 4 8 1} * *$ & $\mathbf{6 . 1 3 3} * *$ \\
& $\mathbf{( 1 . 9 0 1 )}$ & $\mathbf{( 1 . 9 5 9 )}$ & $\mathbf{( 2 . 1 7 1 )}$ & $\mathbf{( 2 . 2 5 6 )}$ & $\mathbf{( 1 . 7 8 1 )}$ & $\mathbf{( 1 . 8 9 7 )}$ \\
Canton fixed effects & YES & YES & YES & YES & YES & YES \\
Year fixed effects & YES & YES & YES & YES & YES & YES \\
Time-varying control variables & NO & YES & NO & YES & NO & YES \\
Observations & 1547 & 1547 & 1547 & 1547 & 1547 & 1547 \\
\hline
\end{tabular}

Sources: Ecuador's National Registries of Live Births for 2008-2017; National Census and population projections.

Notes: Table presents fixed effects regression results using a time-invariant quintile-based definition for highly indigenous cantons; thus the ind 3 variable drops out.

Interaction term represents triple differences (DDD) in birth rates per 1000 women:

Delta 1 is for (teens - young adults)

Delta 2 is for (teens - late 20s)

Delta 3 is for (teens - early 30 s)

Robust standard errors in parentheses clustered at canton level:

$* \mathrm{p}<0.05 * * \mathrm{p}<0.01 * * * \mathrm{p}<0.001$

Under the ind3 time-invariant, quintile definition, a cantón is classified as high indigenous if the percentage of women who self-identified as indigenous across all years (2008-2017) is in the top two quintiles of the national distribution; and low indigenous if that percentage is in the bottom three quintiles of the national distribution. Because ind 3 is time invariant, it drops out as a main effect.

Post 2014 is a dummy variable $=1$ if year $>2014$. Because we have year fixed effects, we do not need Post2014 as a main effect..

Time-varying control variables include cantón-level means for: age, education, proportion Indigenous, married/in-union, institutional delivery, skill birth attendance, any prenatal control, and second-or-higher-order birth. 


\section{Appendix Table A6}

Any Contraception Use, Ever and Currently Used Now, Triple Difference (DDD) Estimation: ENSANUT 2012 and 2018.

(1)

Any contraception method used ever
(2)

Any contraception method currently used now (last 30 days)
Year $=2018$

0.00256

(0.00715)

Teen

Year $=2018 \times$ Teen

IND

Year $=2018 \times I N D$

Teen $\mathrm{x}$ IND
$-0.00289$

(0.0128)

$-0.102 * * *$

(0.0168)

$-0.0129$

0.00161

(0.0204)

$-0.106^{* * *}$

$-0.156^{* * *}$

(0.0229)

(0.0282)

0.0230

0.0264

(0.0304)

(0.0270)
Year $=2018 \times$ Teen $\times$ IND
0.0329

(0.0367)

$-0.111 * *$

(0.0305)

$0.933 * * *$

(0.00855)
0.0307

(0.0523)

$-0.0819$

$(0.0582)$

$0.705^{* * *}$

$(0.0105)$

Constant

12659

12593

Sources: Ecuador National Health and Nutrition Surveys, ENSANUT $\underline{2012}$ and $\underline{2018}$.

Notes: Robust standard errors in parentheses, clustered at the province level.

$* \mathrm{p}<0.05 * * \mathrm{p}<0.01 * * * \mathrm{p}<0.001$

We pooled the last two nationally representative health surveys (ENSANUT 2012 and 2018) as repeated cross-sections and estimated a triple difference (DDD) with contraception use (ever and now as separate dependent variables) against a triple interaction of Post $_{t} \times$ Teen $_{i t} \times I N D_{i t}$ and all the lower level interactions; where Post $t_{t}$ is equal to 1 for the 2018 cross-section, teen is an indicator for teen women, and $I N D_{i t}$ is an indicator for indigenous self-identification for woman $i$ at time $t$. 


\section{Appendix Figure A1}

Sexual Activity and Birth Control Use of Female Teens.

\section{Sexual Activity and Birth Control Use of Female Teens}

Ecuador: 2012 \& 2018

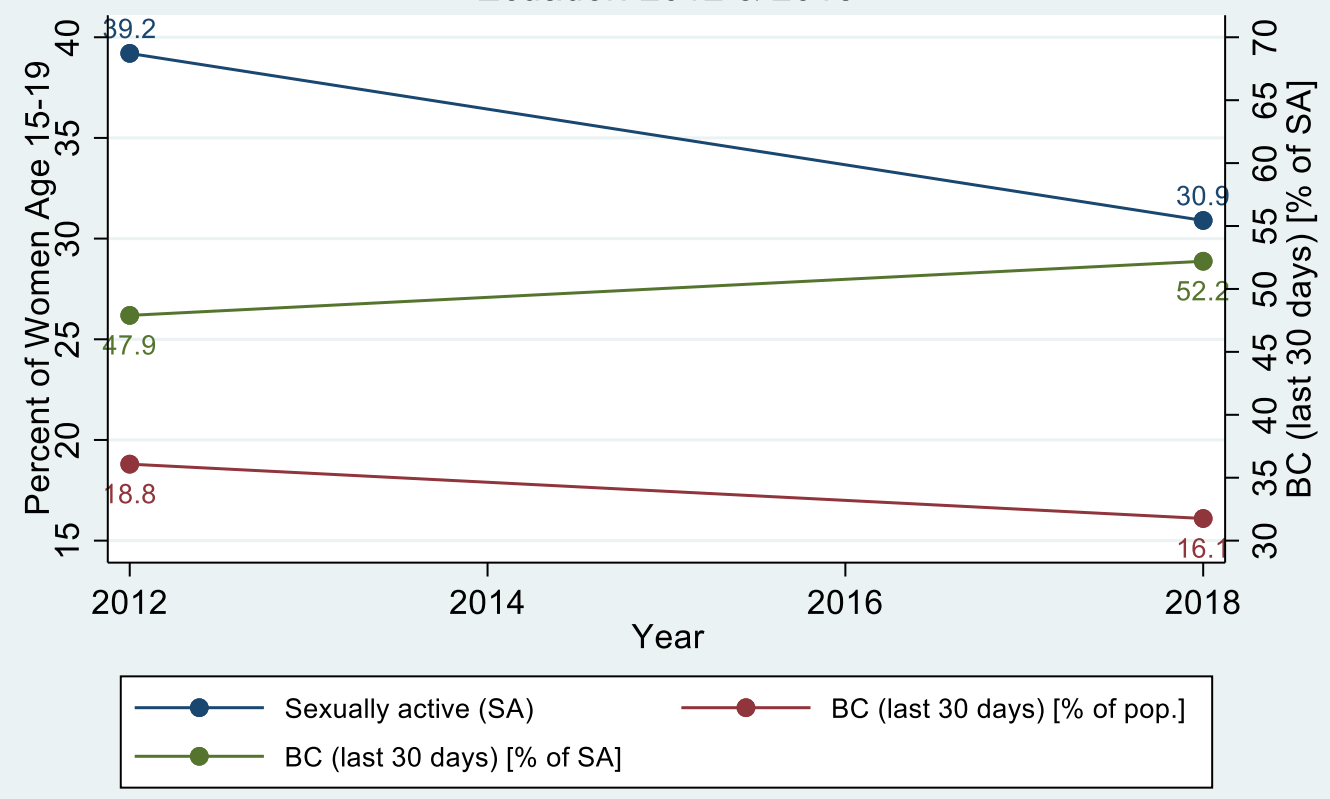

Source: ENSANUT 2012 \& 2018

Notes: We pooled the last two nationally representative health surveys (ENSANUT 2012 and 2018) as repeated cross-sections and plotted percentage of teenage women (15-19 years) who reported to be sexually active (SA) [measured on the left Y-axis] as well as any birth control (BC) use as a percentage of total population and as a percentage of SA [measured on the right Y-axis]. 


\section{Appendix Figure A2}

Indigenous self-identification rates, by age group and year of birth, 2007-2018, random first 18 cantons.
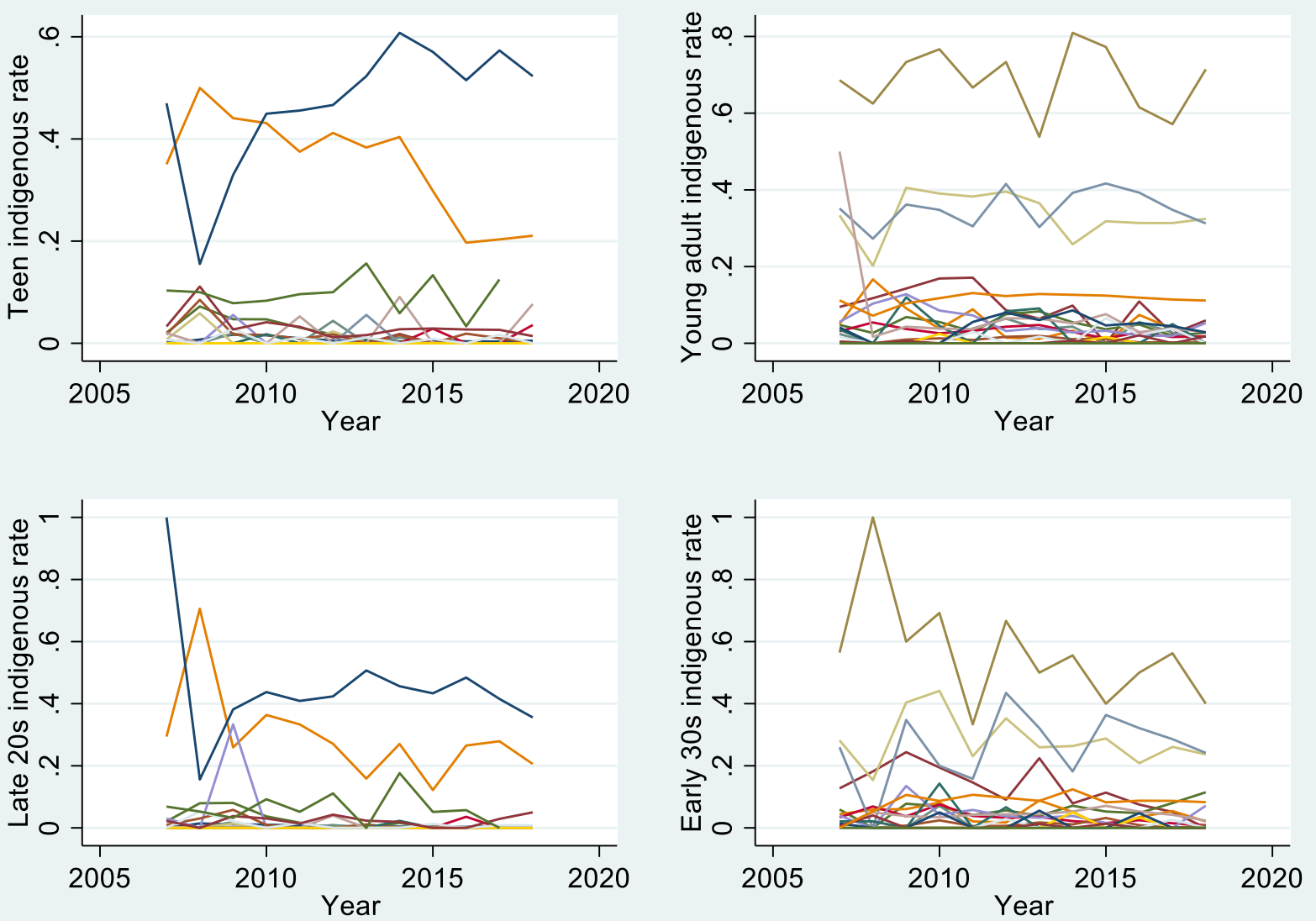

Sources: Ecuador's National Registries of Live Births for 2008-2017; National Census and population projections.

Notes: The figures in Appendix Figure A2 show the trajectories of indigenous self-identification in a random set of the first-observed 18 cantons (out of 221 at the national level) using the Live Births Dataset (Encuesta de Nacidos Vivos, ENV) such that years of observation are presented in the Xaxis, and the percentages of women who self-identify as indigenous are in the Y-axis. Each graph presents the rates for a different age group: teen women (15-19 years), young adult women (20-24), women in their late 20s (25-29), and women in their early 30s (30-34 years). 


\section{Appendix Figure A3}

Indigenous self-identification rates, by age group and year of birth, 2007-2018, random last 18 cantons.
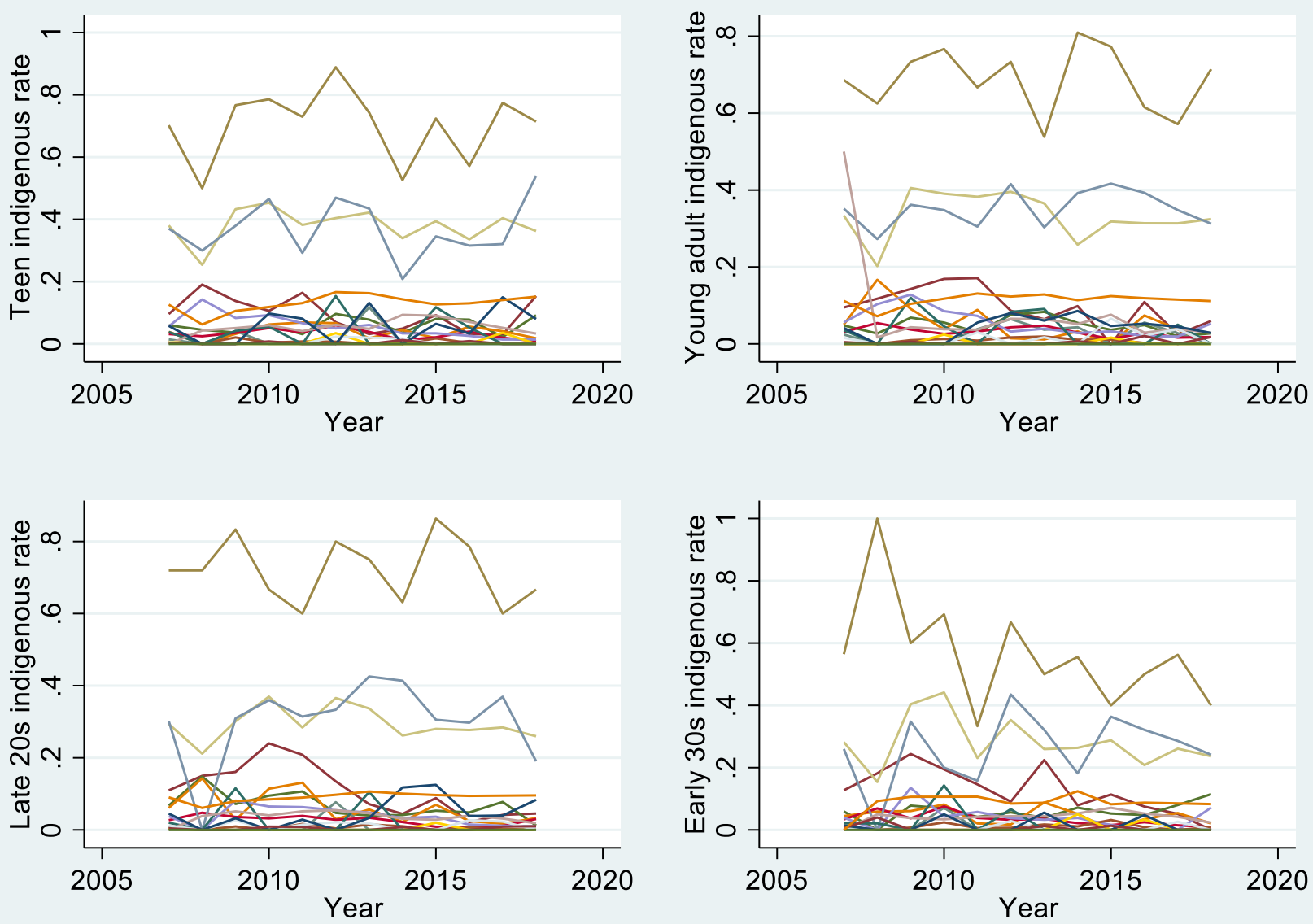

Sources: Ecuador's National Registries of Live Births for 2008-2017; National Census and population projections.

Notes: The figures in Appendix Figure A3 show the trajectories of indigenous self-identification in a random set of the last-observed 18 cantons (out of 221 at the national level) using the Live Births Dataset (Encuesta de Nacidos Vivos, ENV) such that years of observation are presented in the Xaxis, and the percentages of women who self-identify as indigenous are in the Y-axis. Each graph presents the rates for a different age group: teen women (15-19 years), young adult women (20-24), women in their late 20s (25-29), and women in their early 30s (30-34 years). 